\title{
Lichen Depsidones with Biological Interest
}

\author{
Authors \\ Isabel Ureña-Vacas, Elena González-Burgos, Pradeep Kumar Divakar, M. Pilar Gómez-Serranillos
}

\section{Affiliation}

Department of Pharmacology, Pharmacognosy and Botany, Faculty of Pharmacy, Complutense University of Madrid (Spain)

\section{Key words}

secondary metabolites, natural products, pharmacology, antioxidants, antimicrobial, cytotoxic

\section{received}

March 9, 2021

accepted after revision

April 13, 2021

published online

May 25, 2021

Bibliography

Planta Med 2022; 88: 855-880

DOI 10.1055/a-1482-6381

ISSN 0032-0943

(C) 2021. Thieme. All rights reserved.

Georg Thieme Verlag KG, Rüdigerstraße 14,

70469 Stuttgart, Germany

\section{Correspondence}

Dr. Elena González Burgos

Department of Pharmacology, Pharmacognosy and Botany, Faculty of Pharmacy, Complutense University of Madrid (Spain)

Plaza Ramón y Cajal s/n, 28040 Madrid, Spain

Phone: + 34913942276 , Fax: + 34913941624

elenagon@ucm.es

\section{ABSTRACT}

Depsidones are some of the most abundant secondary metabolites produced by lichens. These compounds have aroused great pharmacological interest due to their activities as antioxidants, antimicrobial, and cytotoxic agents. Hence, this paper aims to provide up-to-date knowledge including an overview of the potential biological interest of lichen depsidones. So far, the most studied depsidones are fumarprotocetraric acid, lobaric acid, norstictic acid, physodic acid, salazinic acid, and stictic acid. Their pharmacological activities have been mainly investigated in in vitro studies and, to a lesser extent, in in vivo studies. No clinical trials have been performed yet. Depsidones are promising cytotoxic agents that act against different cell lines of animal and human origin. Moreover, these compounds have shown antimicrobial activity against both Gram-positive and Gram-negative bacteria and fungi, mainly Candida spp. Furthermore, depsidones have antioxidant properties as revealed in oxidative stress in vitro and in vivo models. Future research should be focused on further investigating the mechanism of action of depsidones and in evaluating new potential actions as well as other depsidones that have not been studied yet from a pharmacological perspective. Likewise, more in vivo studies are prerequisite, and clinical trials for the most promising depsidones are encouraged.

\section{Introduction}

Lichens are a unique symbiosis between a fungus belonging to Ascomycota and Basidiomycota phylum (mycobiont) and a chlorophyll-containing partner (photobiont), which is an alga or a cyanobacterium. Moreover, recent studies have identified specific bacterial microbiomes as the third component of lichen [1,2]. Lichens have been traditionally used for their medicinal value as healing (i.e., Heterodermia diademata [Taylor] D.D. Awasthi) and cold (i.e., Everniastrum cirrhatum [Fr.] Hale ex Sipman.), for their culinary value for preparing tea, curry, soup, pickle, and sausages (i.e., Everniastrum nepalense [Taylor] Hale ex Sipman; Cladonia rangiferina [L.] Weber ex F.H. Wigg.), and for their ritual, spiritual, and aesthetic values (i.e., Thamnolia vermicularis [Sw.] Ach. ex Schaer.) [3-5].

Lichens produce unique and diverse secondary metabolites. So far, over 1000 compounds have been identified, including depsi- dones, depsides, dibenzofurans, and xanthones, which are synthesized via the acetate-malonate pathway, pulvinic acid derivatives formed in the shikimic acid pathway, and terpenes and steroids via the mevalonic acid pathway. The amount of these secondary metabolites may vary from $0.1 \%$ to $30 \%$ of the dry weight of the thallus, and they are deposited in both the cortex and the medullary layers. Hence, depsides and dibenzofurans, such as usnic acid (major) and atranorin (trace) in Flavoparmelia caperata L. (Hale) and atranorin and chloroatranorin in Hypogymnia physodes (L.) Nyl., are found in the cortex, whereas depsidones, such as physodic acid, 3-hydroxyphysodic acid, and physodalic acid as major compounds in H. physodes (L.) Nyl., norstictic acid in Parmotrema perforatum (Jacq.) A. Massal., and salazinic acid (major) and consalazinic acids (minor) in Parmelia saxatilis (L.) Ach., are found in the medullary layer [6-9]. These secondary metabolites play a key role in chemotaxonomy and systematics [6]. Moreover, they exert diverse biological functions including protection against 


\begin{tabular}{|c|c|}
\hline \multicolumn{2}{|c|}{ ABBREVIATIONS } \\
\hline 8-OH-dG & 8-Oxo-2'-deoxyguanosine \\
\hline Axin2 & axis inhibition protein 2 \\
\hline Bax & Bcl-2 associated X-protein \\
\hline $\mathrm{Bcl}-2$ & B-cell lymphoma 2 \\
\hline BDNF & brain-derived neurotrophic factor \\
\hline $\operatorname{cox}$ & cyclooxygenase \\
\hline DPPH & 2,2-diphenyl-1-picrilhidrazil \\
\hline FabZ & $\begin{array}{l}\text { 3-hydroxyacyl-[acyl-carrier-protein] } \\
\text { dehydratase }\end{array}$ \\
\hline FAS & fatty acid biosynthesis \\
\hline GSH & reduced glutathione \\
\hline HGF & hepatocyte growth factor \\
\hline Hsp70 & 70 kD heat shock proteins \\
\hline HSV & herpes simplex virus \\
\hline IL-1 & interleukin-1 \\
\hline JAK/STAT & $\begin{array}{l}\text { janus kinase/signal transducers and } \\
\text { activators of transcription }\end{array}$ \\
\hline LPS & lipopolysaccharide \\
\hline MAPK & mitogen-activated protein kinases \\
\hline MIC & minimum inhibitory concentration \\
\hline MMP7 & matrix metalloproteinase-7 \\
\hline MPP1 & M-Phase Phosphoprotein 1 \\
\hline MRSA & methicillin-resistant Staphylococcus aureus \\
\hline NF-к $\beta$ & $\begin{array}{l}\text { nuclear Factor kappa-light-chain-enhancer } \\
\text { of activated B cells }\end{array}$ \\
\hline NGF & nerve growth factor \\
\hline NLRP3 & $\begin{array}{l}\text { NOD-, LRR- and pyrin domain-containing } \\
\text { protein } 3\end{array}$ \\
\hline NOS & nitric oxide synthase \\
\hline Nrf2 & nuclear factor E2-related factor 2 \\
\hline nsP1 & nonstructural protein 1 \\
\hline ORAC & oxygen radical absorbance capacity \\
\hline PAR2 & proteinase-activated receptor-2 \\
\hline PARP & poly (ADP-ribose) polymerase \\
\hline PF-UVA & protection Factor-ultraviolet A \\
\hline PI3K & phosphatidylinositol 3-kinase \\
\hline PKS & polyketide synthase \\
\hline Plk1 & polo-like kinase-1 \\
\hline PTP1B & protein tyrosine phosphatase $1 \mathrm{~B}$ \\
\hline RNS & reactive nitrogen species \\
\hline ROS & reactive oxygen species \\
\hline SLIGKV-NH 2 & Ser-Leu-Ile-Gly-Lys-Val-amide \\
\hline SOR & scavenging superoxide radicals \\
\hline TNF- $\alpha$ & tumor necrosis factor- $\alpha$ \\
\hline TRAIL & TNF-related apoptosis-inducing ligand \\
\hline Trp-P-2 & tryptophan pyrolysis product-2 \\
\hline
\end{tabular}

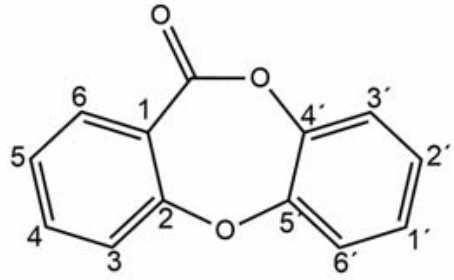

- Fig. 1 General structure of depsidones.

dones consist of a polycyclic system linked through an ether group and an ester group, giving the rigid $11 \mathrm{H}$-dibenzo[b,e][1,4] dioxepin-11-one ring ( $\bullet$ Fig. 1) [14-16]. The biosynthesis of depsidones occurs via the acetate-malonate pathway, with acetylCoenzyme $A$ as the precursor and PKS as the responsible enzyme ( $\bullet$ Fig. 2) [17]. Several bioactive depsidones such as stictic acid, salazinic acid, and psomoric acid have been identified [18-20]. The chemical structures of different depsidones of lichens are depicted in $>$ Fig. 3.

This paper aims to provide up-to-date knowledge and an overview of the biological interest of lichen depsidones. This review includes pharmacological information for those depsidones that have been investigated with potential bioactivity. Original papers published in English in PubMed/Medline and Scholar Google without date restriction were included. Those articles with lichen extracts rich in depsidones were excluded from this review. It is important to emphasize that more depsidones have been identified, such as notatic acid, nortotatic acid, and diploicin, but their pharmacological activities have not been investigated yet.

\section{Chemistry and Biochemical Origin}

The depsidones and the majority of other secondary metabolites in lichens are produced by lichen-forming fungi and are deposited on the outer surface of the hyphal cell walls in the medullary layer of the lichen thallus ( $\mathbf{F i g . 4}$ ) [21]. The interactions between the mycobiont and photobiont affect the production of secondary metabolites in lichens. For example, several studies have shown that mycobionts within the lichen thallus produce a variety of secondary metabolites in contrast with axenic mycobiont cultures [22-24]. The production of secondary metabolites in the lichen thallus has also been found to be affected by environmental factors (i.e., UV-radiation, climatic conditions, habitats, and presence of non-photosynthetic bacteria and other fungi in lichen thallus) [25-30].

Depsidones consist of 2 or rarely 3 aromatic rings joined by ester linkages and an ether linkage between the rings. The rings are based on the structure of orsellinic acid. Depsidones are grouped in an orcinol or B-orcinol series, depending on the presence of a $\mathrm{CH}_{3}$ on the $\mathrm{C} 3$ carbon of their rings ( $\bullet$ Fig. 1) [31-33].

Acetate and malonate units are condensed to form orsellinic acid or B-orsellinic acid that is a precursor for the biosynthesis of several secondary metabolites in lichens and fungi in general ( $\bullet$ Fig. 2). Depsides are produced by the condensation of 2 or 


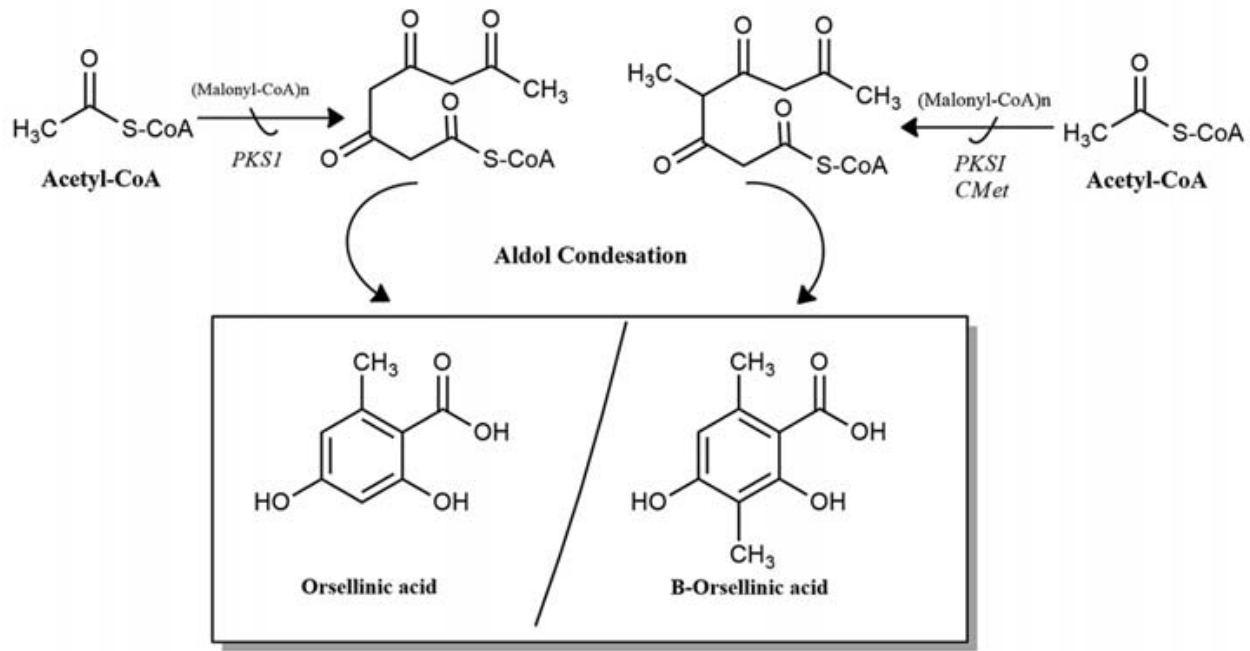<smiles>[R8]c1c(O)cc(C)c(C(=O)O)c1O</smiles><smiles>[R7]c1c(O)cc(C)c(C(=O)Oc2cc(C)c(C(=O)O)c(O)c2[R7])c1O</smiles>

Orcinol $/ \mathbf{R}_{1}=\mathbf{C H}_{3}$ : B-Orcinol Depsides<smiles>[R]c1c(O)c(C(=O)O)c(C)c2c1OC(=O)c1c(C)cc(O)c([R])c1O2</smiles>

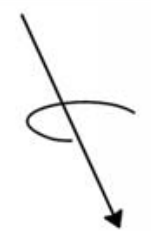<smiles>Oc1cccc(O)c1</smiles>

Orcinol derivatives<smiles>[R]c1cccc(OC(=O)c2c(C)cc(O)c(Br)c2O)c1</smiles><smiles>C[12CH3]</smiles><smiles>[R]c1cc2c(c([R])c1O)OC(=O)c1c(C)cc(O)cc1O2</smiles>

\footnotetext{
Orcinol/ $\mathrm{R}_{1}=\mathrm{CH}_{3}:$ B-Orcinol

Depsidones
}

- Fig. 2 Biosynthesis of depsidones.

more hydroxybenzoic acids through which the carboxyl group of 1 molecule is esterified with a phenolic hydroxyl group of a second molecule. Depsides are precursors for the biosynthesis of depsidones [34]. It is widely accepted that the depsidones are formed from depsides by a loss of hydrogen in an oxidative cyclization process ( $\bullet$ Fig. 2 ) $[35,36]$. Several depside-depsidone pairs are found in lichens, for example, Pseudevernia furfuracea contains the depside-depsidone pair (i.e., olivetoric acid and physodic acid) [37]. O-methylation (methylation of oxygen) is a common process and the cause of chemical variation in depsidones in lichens [36]. However, from chemical synthesis producing high yields of several depsidones, it is proposed that depsidones are biosynthesized in 4 steps: by hydroxylation, acyl group migration, Smiles rearrangement, and esterification [38].

Both the depside and depsidones are products of a nonreducing PKS encoded in the genome of the mycobiont [26, 39]. Therefore, the phylogenetic studies of PKS domains, sequencing of complete PKS gene clusters, and the availability of whole-genome sequence data have enabled a more detailed study of the biosynthetic origin of the nonreducing polyketides in lichens [40-44]. 
<smiles>CCCCCC(=O)Cc1cc(O)cc2c1C(=O)Oc1cc(O)c(C(=O)O)c(CC(=O)CCCCC)c1O2</smiles>

$\alpha$-alectoronic acid<smiles>CCCCCC(=O)Cc1cc(OC)cc2c1C(=O)Oc1cc(O)c(C(=O)O)c(CC(=O)CCCCC)c1O2</smiles>

$\alpha$-Collatolic acid<smiles>COc1cc(C)c2c(c1CO)Oc1c(c(C)c(O)c3c1C(O)OC3=O)OC2=O</smiles>

Cryptostictic acid<smiles>CCOC1OC(=O)c2c(O)c(C)c3c(c21)Oc1c(O)c(OC)cc(C)c1C(=O)O3</smiles>

Ceratinalone<smiles>Cc1cc(O)c(C)c2c1C(=O)Oc1c(CO)c(O)c(C(=O)O)c(C)c1O2</smiles>

\section{Conhypoprotocetraric}<smiles>Cc1cc(O)c(CO)c2c1C(=O)Oc1c(C)c(O)c3c(c1O2)C(O)OC3=O</smiles><smiles>CCOC1OC(=O)c2c(O)c(C)c3c(c21)Oc1c(C)cc(OC)c(C=O)c1O3</smiles>

8'-O-ethylstictic<smiles>COc1cc(C)c2c(oc3c4c(c(O)c(O)c3oc(=O)c3c(CO)cc(OC)c(O)c32)C(=O)OC4O)c1C=O</smiles><smiles>COc1cc2c(c(C)c1Cl)C(=O)Oc1c(C)c(OC)c(Cl)c(C)c1O2</smiles>

Flavicansone 
<smiles>Cc1cc(O)c(C=O)c2c1C(=O)Oc1c(COC(=O)/C=C/C(=O)O)c(O)c(C(=O)O)c(C)c1O2</smiles>

Fumarprotocetraric acid<smiles>Cc1cc(O)c(C)c2c1C(=O)Oc1c(C)c(O)c(C(=O)O)c(C)c1O2</smiles>

Hypoprotocetraric<smiles>COc1cc(C)c2c(c1C=O)Oc1c(c(C)c(O)c3c1C(OC)OC3=O)OC2=O</smiles>

8'-0-methylstictic acid<smiles>COc1cc(C)c2c(c1C(=O)O)Oc1c(c(C)c(O)c3c1C(O)OC3=O)OC2=O</smiles>

Peristictic acid<smiles>COC(=O)c1c(OC)cc2c(c1C)Oc1c(Cl)c(O)c(Cl)c(C)c1C(=O)O2</smiles>

Gangaleoidin<smiles>COc1cc(C)c2c(c1C)Oc1c(c(C)c(O)c3c1C(O)OC3=O)OC2=O</smiles>

Hypostictic acid<smiles>Cc1cc(O)c(C=O)c2c1C(=O)Oc1c(C)c(O)c3c(c1O2)C(O)OC3=O</smiles>

Norstictic acid<smiles>CC(=O)OCc1c(O)c(C(=O)O)c(C)c2c1OC(=O)c1c(C)cc(O)c(C=O)c1O2</smiles>

Physodalic acid<smiles>CCCCCC(=O)Cc1cc(O)c(O)c2c1C(=O)Oc1cc(O)c(C(=O)O)c(CCCCC)c1O2</smiles>

3-hydroxyphysodic acid<smiles>CCCCCc1c2c(cc(O)c1C(=O)O)OC(=O)c1c(cc(OC)cc1C(=O)CCCC)O2</smiles>

Lobaric acid<smiles>COc1cc(C)c2c(c1C)OC(=O)c1c(C)c(Cl)c(O)c(C=O)c1O2</smiles>

Pannarin

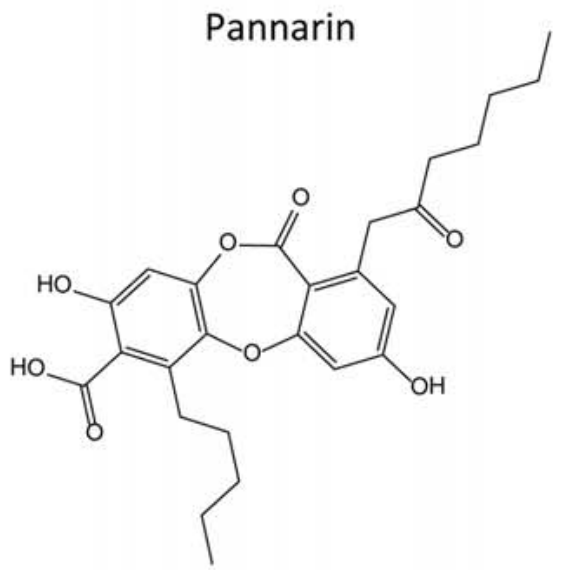

Physodic acid 
<smiles>CCCCCC(=O)Cc1cc(O)cc2c1C(=O)Oc1cc(O)c(C(=O)O)c(CCCCC)c1O2</smiles>

\section{Protocetraric acid}<smiles>COc1cc(C)c2c(c1C=O)Oc1c(c(C)c(O)c3c1C(O)OC3=O)OC2=O</smiles>

Stictic acid<smiles>COc1cc(C(=O)O)c2c(c1C)OC(=O)c1c(C)cc(O)c(C=O)c1O2</smiles>

Psoromic acid<smiles>Cc1cc(O)cc2c1C(=O)Oc1cc3c(c(O)c1O2)C(=O)OC3</smiles>

Variolaric acid<smiles>Cc1cc(O)c(C=O)c2c1C(=O)Oc1c(CO)c(O)c3c(c1O2)C(O)OC3=O</smiles>

Salazinic acid<smiles>COc1c(C)c2c(c(C)c1Cl)Oc1c(C)c(O)c(Cl)c(C)c1C(=O)O2</smiles>

Vicanicin

- Fig. 3 Continued

\section{Molecular Mechanism of Action of Lichen Depsidones}

Little is known about the molecular mechanisms through which depsidones exhibit their activities. This review presents some examples; however, further studies are needed to elucidate the diverse properties of this group of secondary metabolites in lichens.

One of the most investigated activities in lichens is their antioxidant activity. Depsidones have been demonstrated to act as antioxidants by directly scavenging ROS and RNS and by modulating redox enzyme activity and expression (i.e., superoxide dismutase and catalase) and transcription factors expression (i.e., Nrf2) [45]. Depsidones can incorporate into cellular lipid microdomains that make them more efficient as antioxidants than other lichen secondary metabolites [46].

Depsidones have also shown cytotoxic activity against diverse cancer cell lines (i.e., melanoma, breast, and colon). These bioactive compounds exert cytotoxic effects through diverse signaling pathways. Hence, depsidones can attenuate cell tumor growth by acting as selective inhibitors of Plk1 activity. Plk1 is a serine/threonine kinase that is overexpressed in human tumors, and it is related to invasive potential and lower cancer-related survival [47]. In addition, depsidones also directly target antiapoptotic Bcl-2

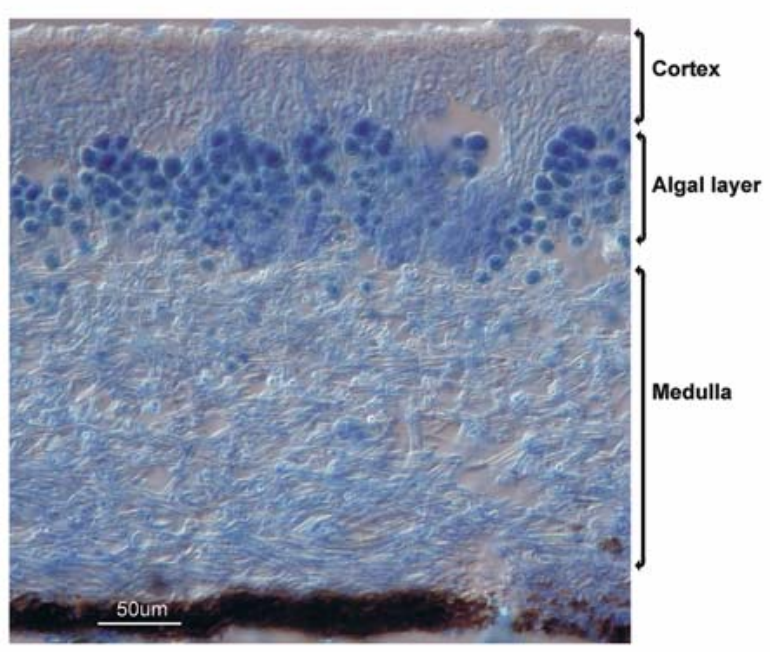

Fig. 4 Cross-section of lichen thallus showing cortical and medullary hyphae. 
family proteins [48]. High expression of antiapoptotic Bcl-2 family proteins (i.e., $\mathrm{Bcl}-2$ ) contributes to the expansion of malignant cells and reduces the therapeutic efficacy of cytotoxic drugs [49]. Moreover, these secondary metabolites are promising cytotoxic agents via oxidative stress induction; the overproduction of ROS disrupts redox homeostasis and leads to severe structural and functional injury in cancer cells [50]. Furthermore, depsidones inhibit lipoxygenases, which are involved in cell viability and proliferation, and migration, invasion, and metastasis of cancer cells [51]. Besides, depsidones can suppress carcinomas by targeting the HGF-c-Met signaling pathway [52]. c-Met is a receptor tyrosine kinase, and HGF is the ligand for this receptor. Dysregulation of the HGF-c-Met signaling pathway promotes tumor progression and metastasis by stimulating different signaling pathways as JAK/ STAT and PI3K/AKT [53]. Finally, other depsidones act as cytotoxic agents by targeting the aberrant Wnt/ $\beta$-catenin signaling [20].

Depsidones have also antimicrobial properties against Grampositive bacteria, Gram-negative bacteria, and fungi. Particularly, some depsidones are RecA inhibitors, which potentiate bactericidal activity and reduce antibiotic resistance [54]. Moreover, depsidones have also targeted the $\beta$-hydroxyacyl-acyl carrier protein FabZ of the bacterial system for FAS [55]. Furthermore, depsidones have proven to be promising antiviral agents against alphaviruses via nsP1 GTP binding and guanylation inhibition. These RNA viruses need a 5'cap structure in whose formation viral protein nsP1 participates and which is necessary to avoid viral RNA degradation [56].

Other depsidones are reported for pharmacological inhibition of protein tyrosine phosphatase $1 \mathrm{~B}$ (involved in insulin resistance) [57]. Moreover, these compounds act in other signal transduction pathways such as epidermal growth factor receptor, integrin signaling pathways, and cell cycle regulation [58]. Furthermore, they have anti-inflammatory properties by inhibiting cytokine expression and NO production through NF-KB/MAPK and inflammasome NLRP3 pathways $[59,60]$.

\section{Pharmacological Activity of Lichen Depsidones}

Pharmacological activities of lichen depsidones are summarized in - Table 1.

\section{Alectoronic acid}

Alectoronic acid has been shown to have cytotoxic activity against the B16 murine melanoma cell line. It reduced cancer cell viability with a higher potency than the reference compound cisplatin (IC 50 of $10.3 \mu \mathrm{M}$ for alectoronic acid and $\mathrm{IC}_{50}$ of $30.3 \mu \mathrm{M}$ for cisplatin) $[61]$.

\section{Collatolic acid}

Collatolic acid showed antimicrobial properties against methicillin-resistant clinical isolates strains of Staphylococcus aureus with an $\mathrm{MIC}_{90}$ value of $128 \mu \mathrm{g} / \mathrm{mL}$. Moreover, combinations of collatolic acid and gentamicin led to a synergistic antimicrobial effect, whereas antagonism occurred when collatolic acid and levofloxacin were associated [62]. Additional antimicrobial action against Escherichia coli RecA protein has been reported for collatolic acid. This compound exhibited a percentage of RecA inhibition of
$103.4 \%$, and it acted as a noncompetitive inhibitor for ATP binding site [63].

\section{Fumarprotocetraric acid}

Fumarprotocetraric acid has been mainly investigated for its antimicrobial properties. Hence, this compound showed antimicrobial action against Gram-positive bacteria (especially Bacillus cereus and Bacillus subtilis with MIC values of $4.6 \mu \mathrm{g} / \mathrm{mL}$ ), Gramnegative bacteria (especially, Listeria monocytogenes with MIC value of $4.6 \mu \mathrm{g} / \mathrm{mL}$ ), and fungi (Candida albicans and Candida glabrata with MIC values of $18.7 \mu \mathrm{g} / \mathrm{mL}$ ) in the disk diffusion method [64]. In another study, this depsidone was more active against bacteria than fungi, and its action against Klebsiella pneumoniae (MIC value of $0.031 \mathrm{mg} / \mathrm{mL}$ ) was particularly remarkable [65]. However, fumarprotocetraric acid has resulted to be ineffective towards MRSA strains [66]. Apart from its antibacterial activity, fumarprotocetraric acid showed antitrypanosomal activity against Trypanosoma brucei brucei [67].

In addition to antimicrobial properties, fumarprotocetraric acid is a promising antioxidant compound. The neuroprotection exerted in neuroblastoma and astrocytoma cell lines by fumarprotocetraric acid has been related to its ability to reduce ROS formation, lipid peroxidation, and GSH depletion [68]. Moreover, fumarprotocetraric acid demonstrated in vivo expectorant and antioxidant properties in an albino Swiss mice model at 25 and $50 \mathrm{mg} /$ $\mathrm{kg}$ as evidenced in an increase of excretions and a reduction of lipid peroxidation in lung tissue [69].

Finally, fumarprotocetraric acid did not show photoprotective properties (SPF value [1.91] and PF-UVA value [1.75]) [70].

\section{3-Hydroxyphysodic acid}

This compound induced cytotoxicity against rat thymocytes and diminished their proliferation via antioxidant/oxidant imbalance [71]. In addition, 3-hydroxyphysodic showed antimicrobial activities. It acted as a larvicidal agent against second and third instar larvae of the mosquito Culiseta longiareolata ( $\mathrm{LC}_{50}$ values $0.97 \mathrm{ppm}$ ) as well as antibacterial and antifungal agent with MIC values from 0.08 to $2.57 \mathrm{mM}$ against B. cereus, E. coli, L. monocytogenes, Salmonella typhimurium, S. aureus, and C. albicans [72, 73].

\section{Lobaric acid}

The in vitro cytotoxic activity of lobaric acid has been tested in many different cancer cell lines such as human breast adenocarcinoma MCF-7 cells, human colon carcinoma HCT-116 cells, and human malignant glioma U87MG cells [48,50,74-77]. Lobaric acid effectively reduced cancer cell viability and proliferation, targeting the anti-apoptotic $\mathrm{Bcl}-2$ protein and the cleaved form of the PARP [48]. This depsidone also exerted cytotoxic action via oxidative stress induction as evidenced in high levels of $8-\mathrm{OH}-\mathrm{dG}$ (DNA damage) [50]. Further, lobaric acid reduced cancer cell growth through the inhibition of 5-lipoxygenase and 12-lipoxygenase $[74,75,77]$. Furthermore, this compound inhibited the polymerization of tubulin in a concentration-dependent manner, and this activity is structurally related to hydroxyl groups at C $-1^{\prime}$ and C-2' $^{\prime}$ and carboxylic acid [78]. Finally, lobaric acid also inhibited mitochondrial thioredoxin reductase in rat lungs [79]. 


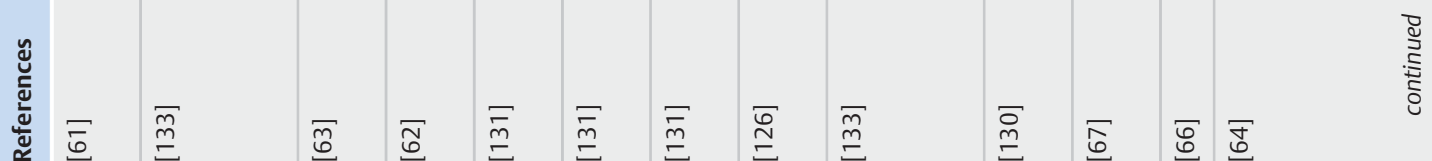

E

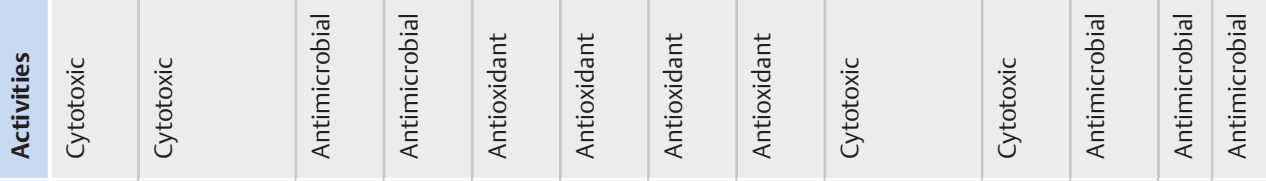

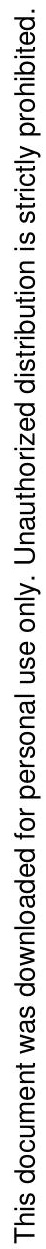

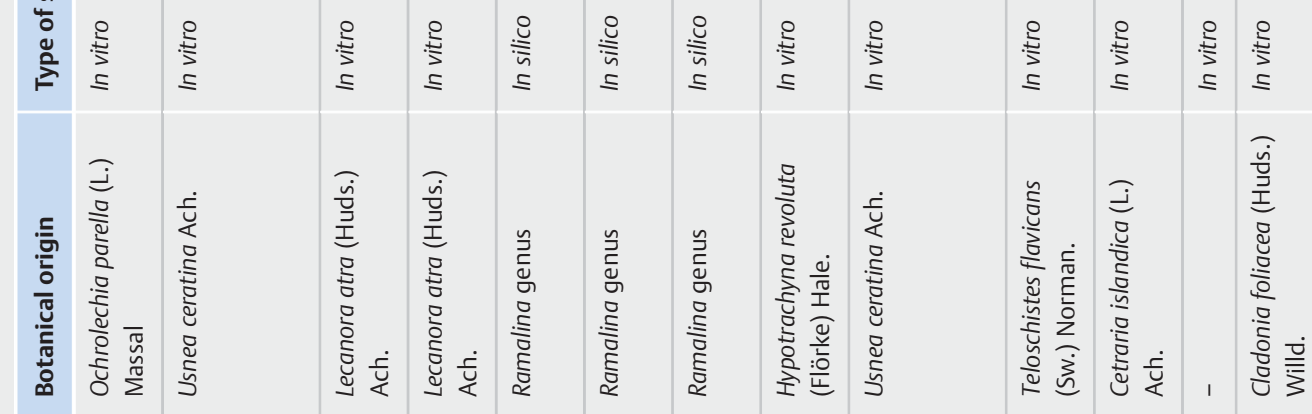

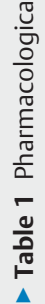

量

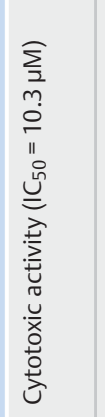

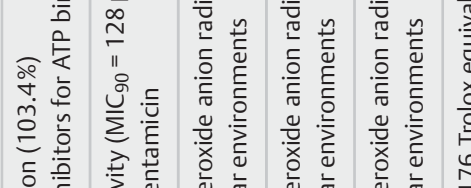

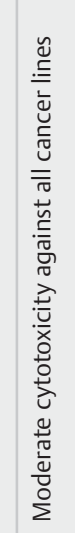

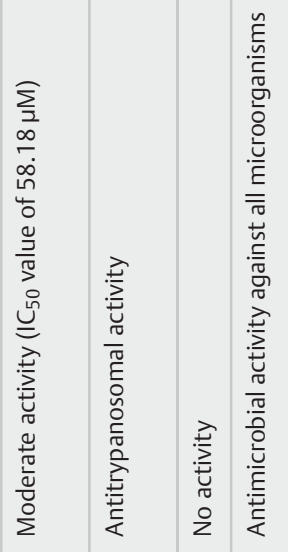

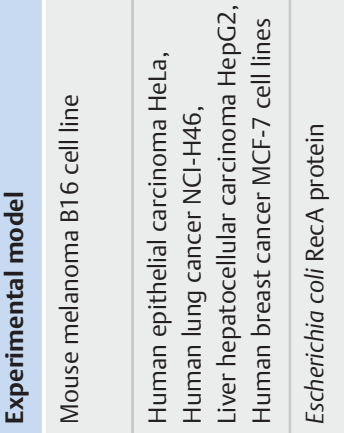

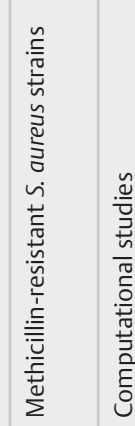

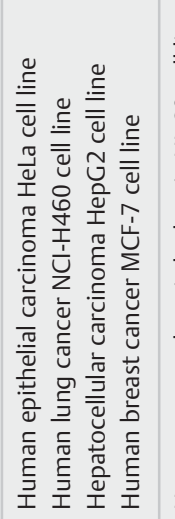

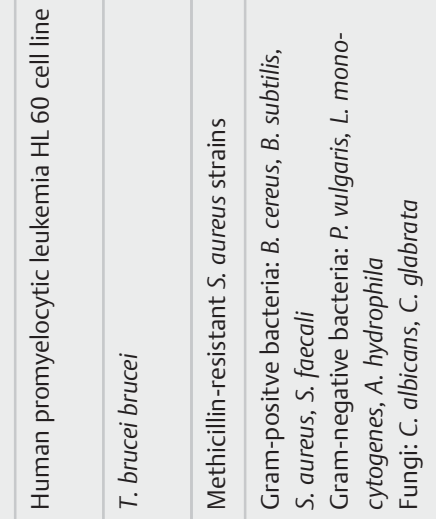

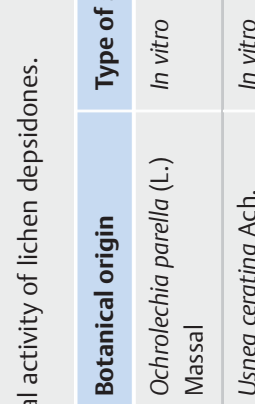

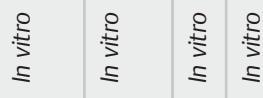

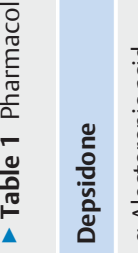

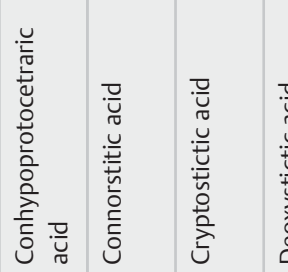

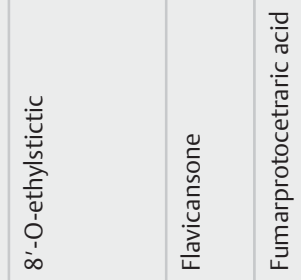




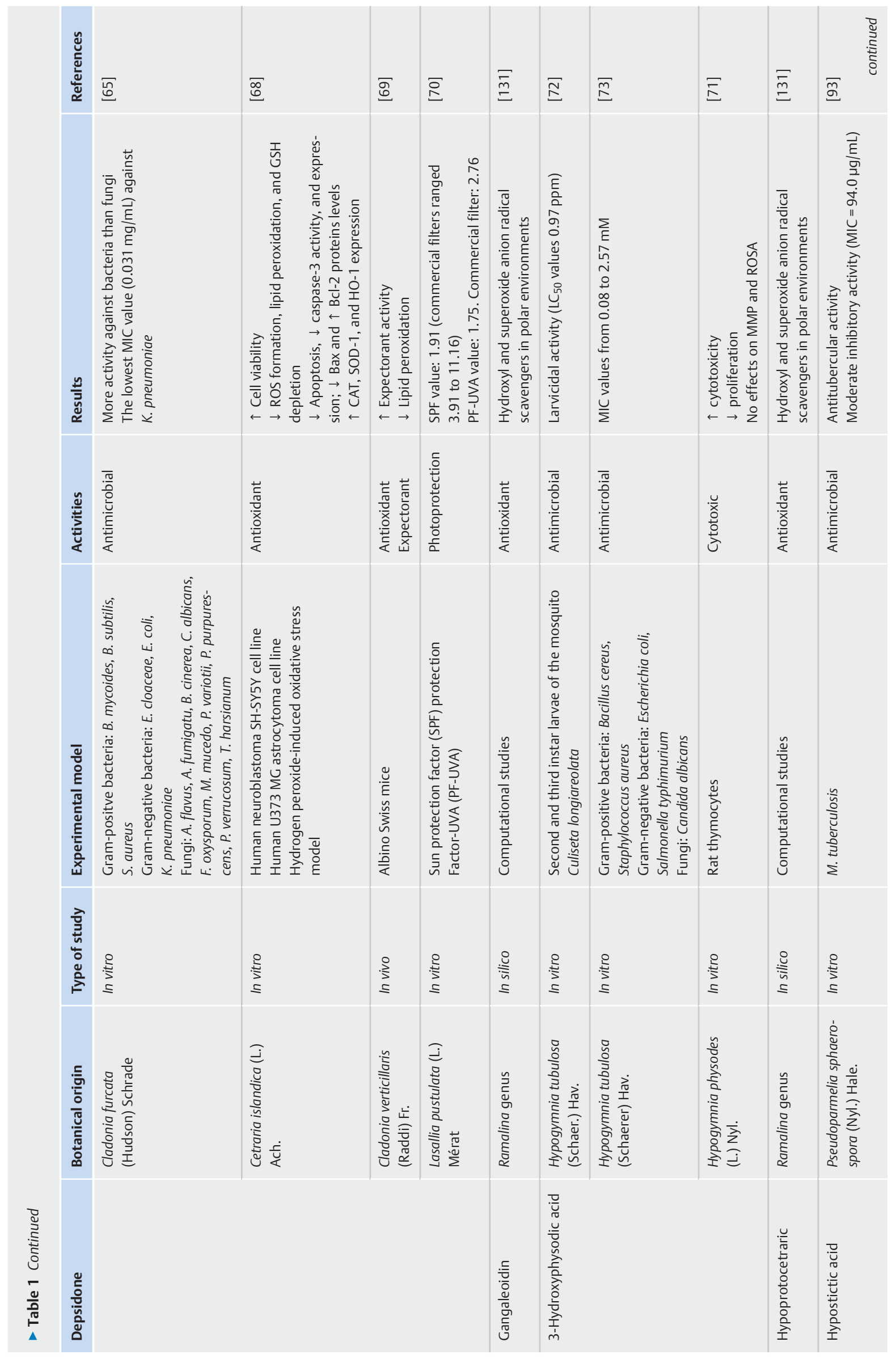




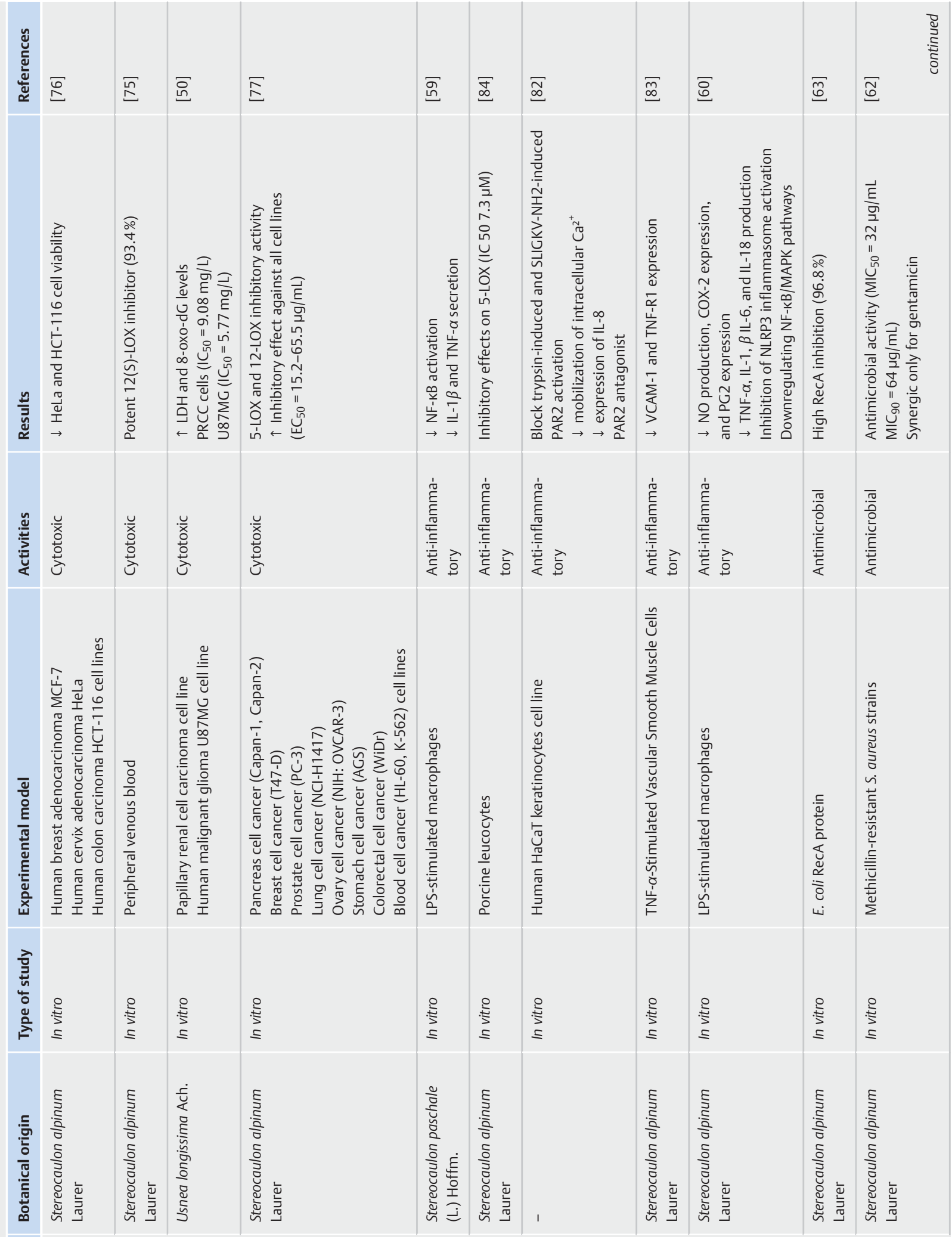

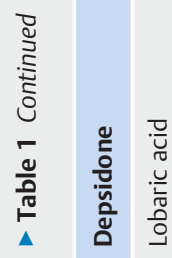




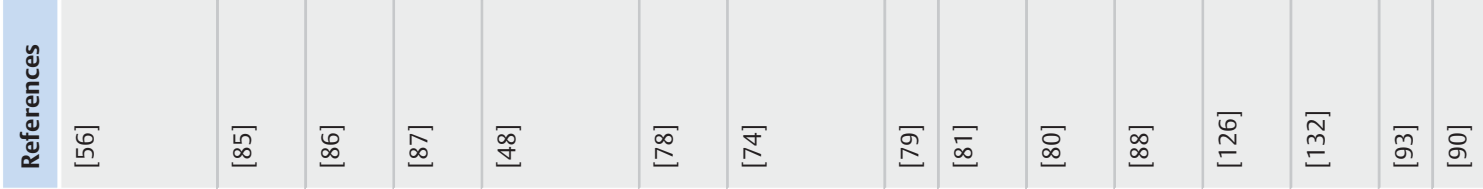

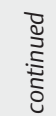

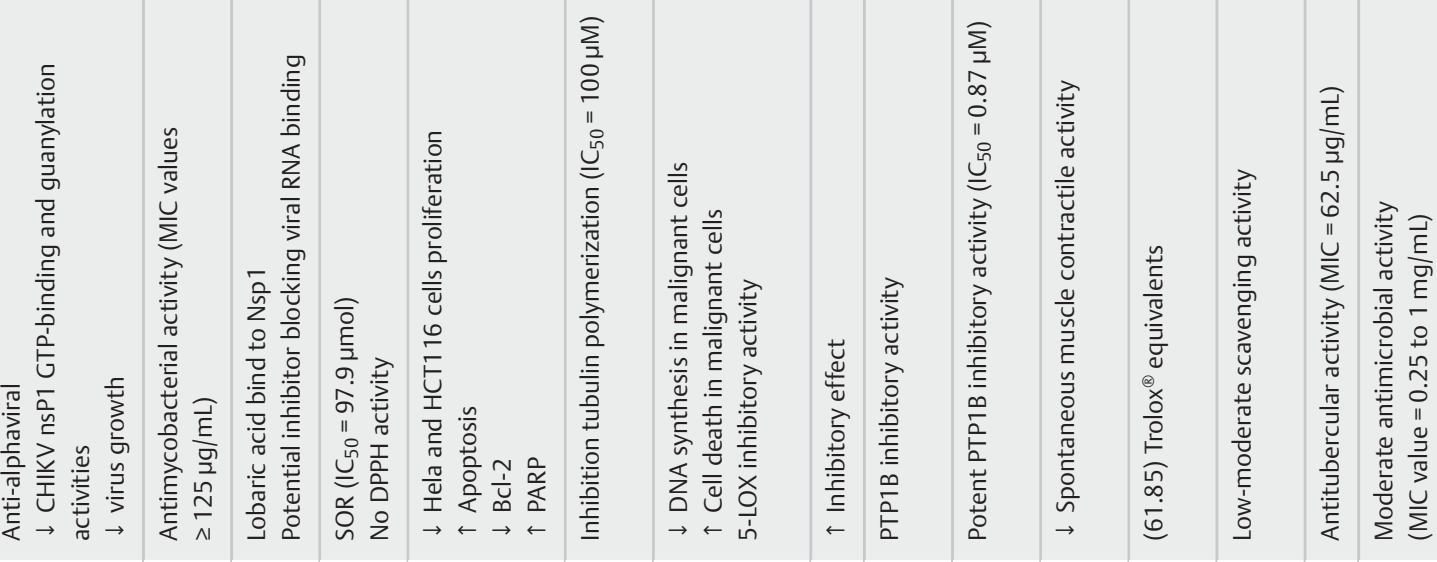

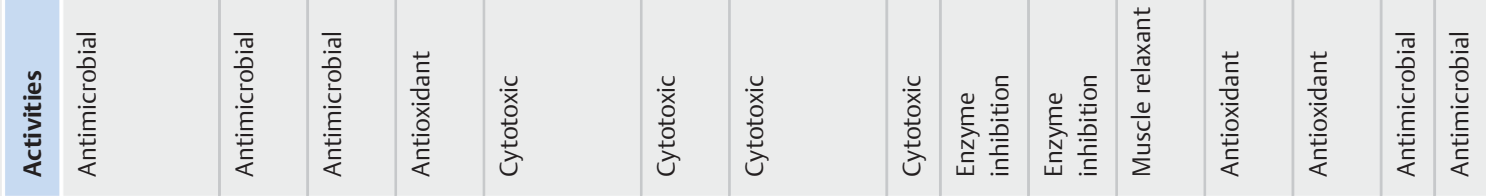

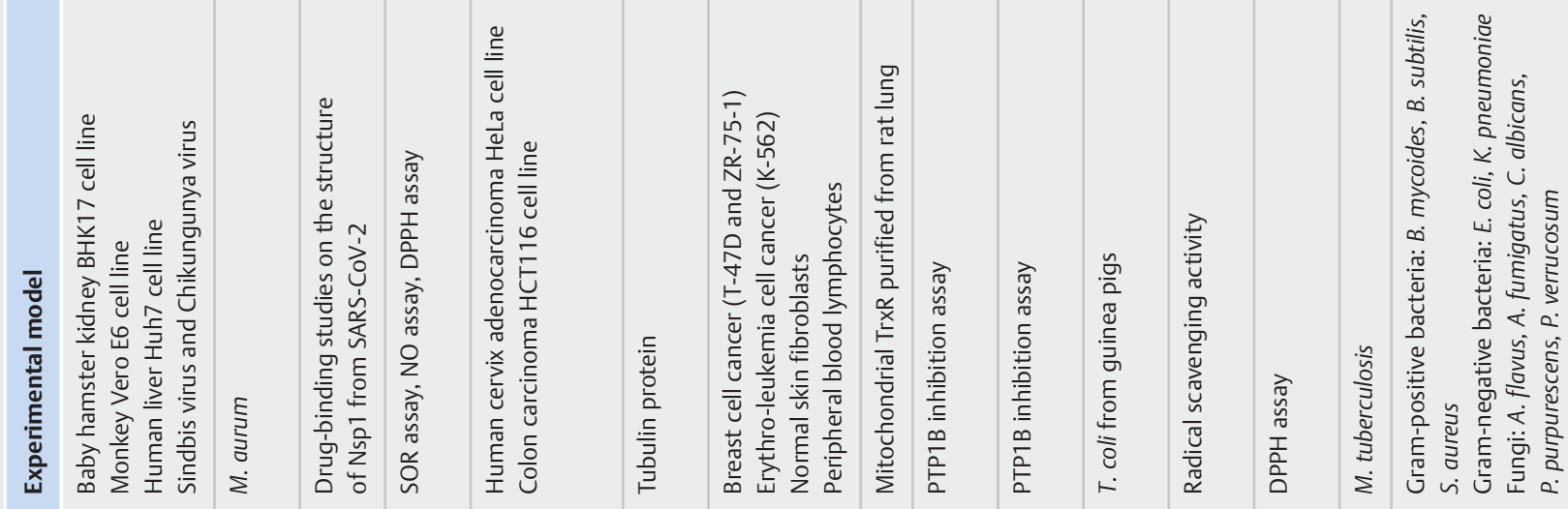

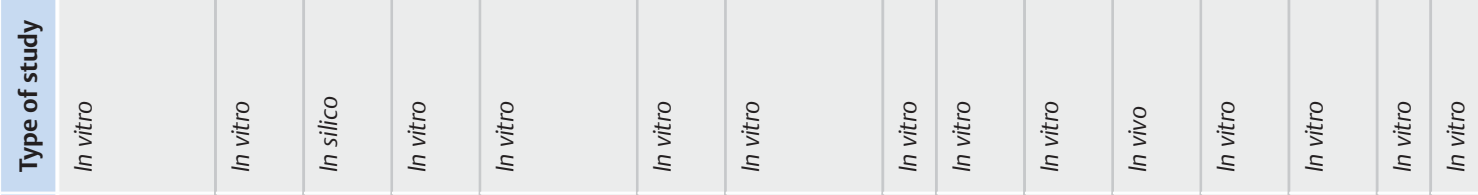

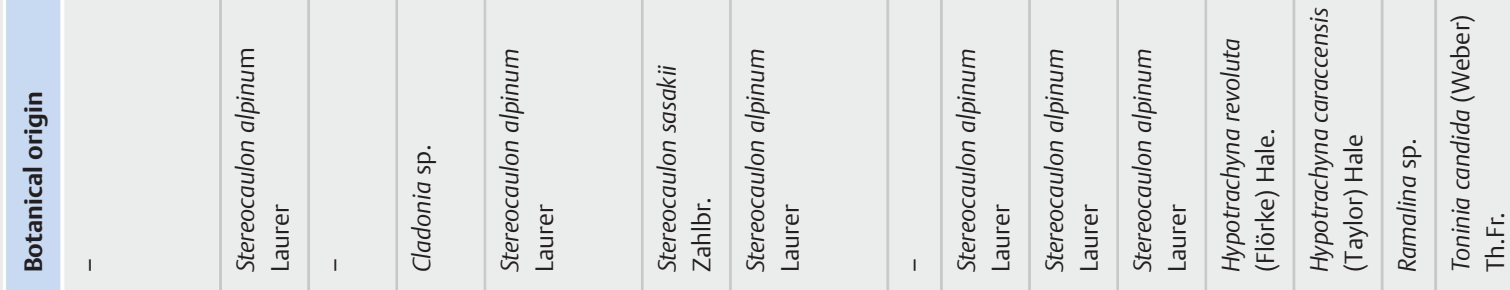
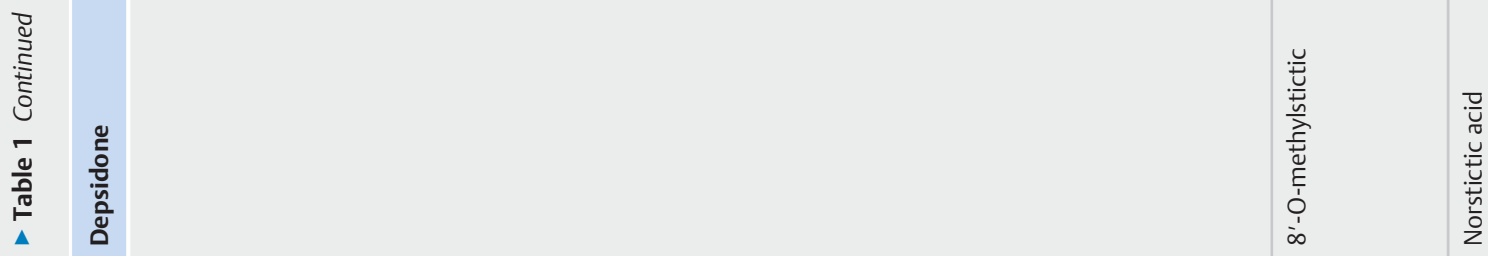


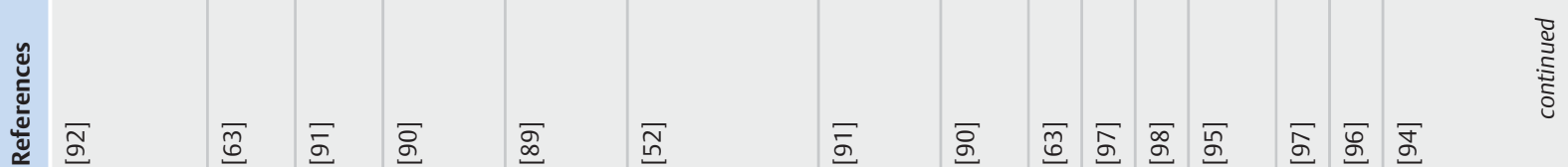

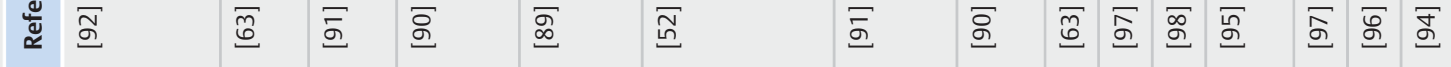

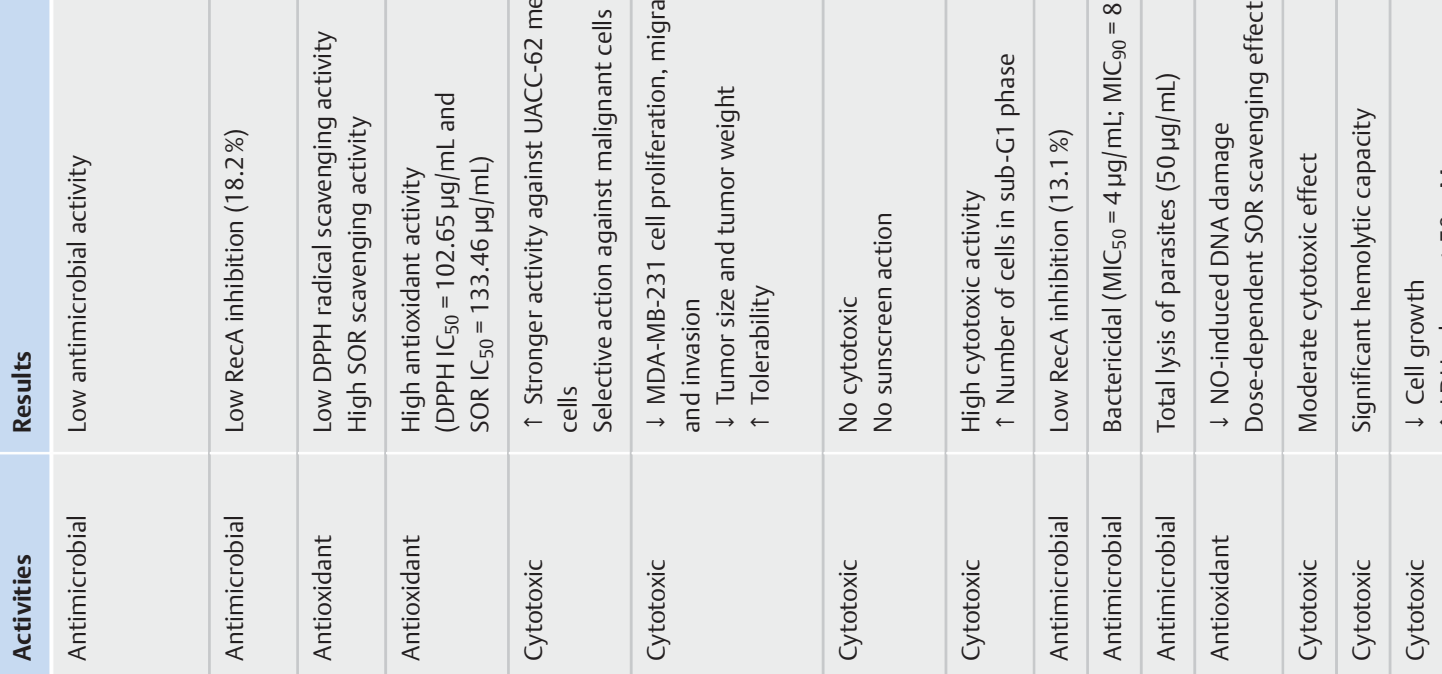<smiles>[Li][13CH]</smiles>

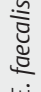

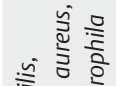

药

की

ब

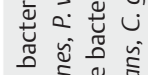

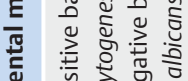

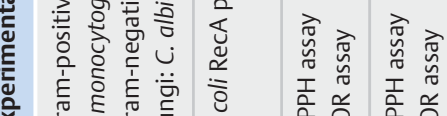

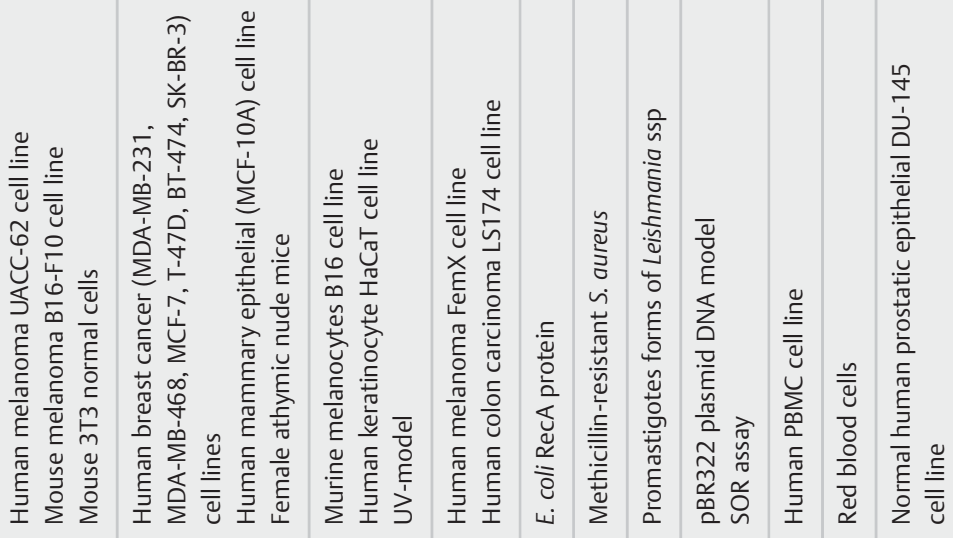

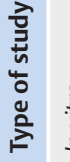

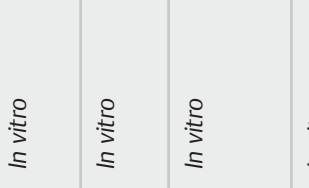

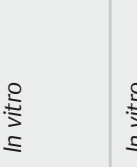

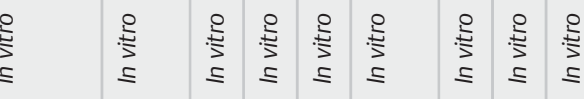

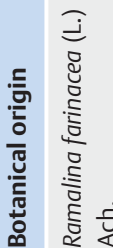

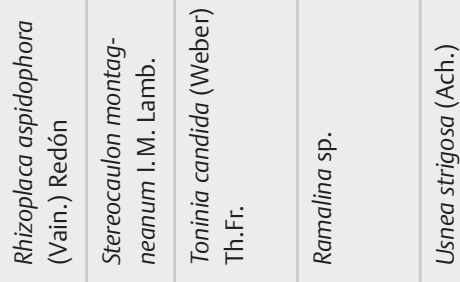

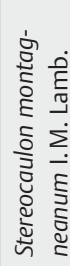
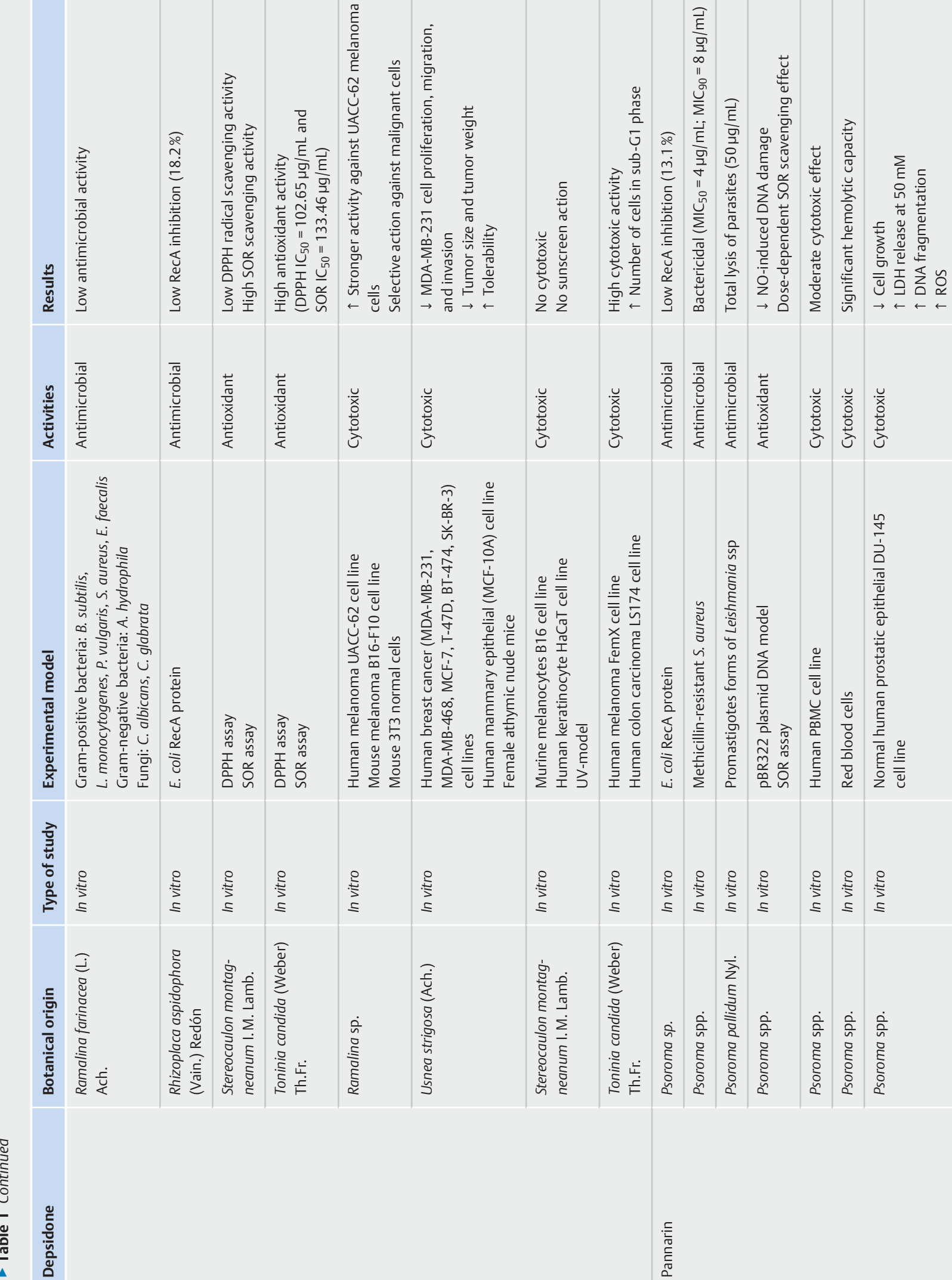


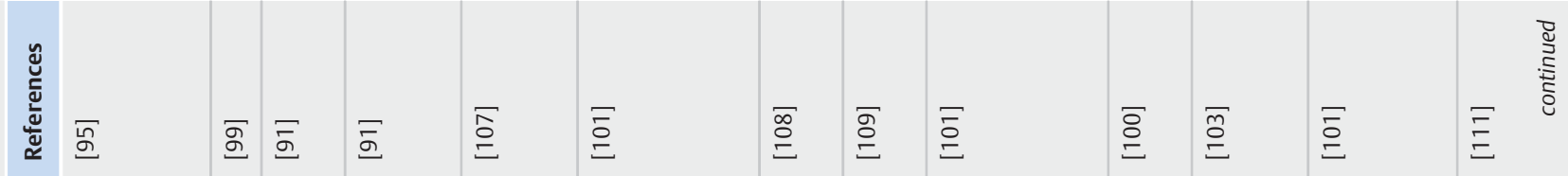

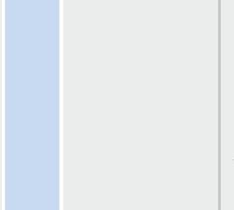
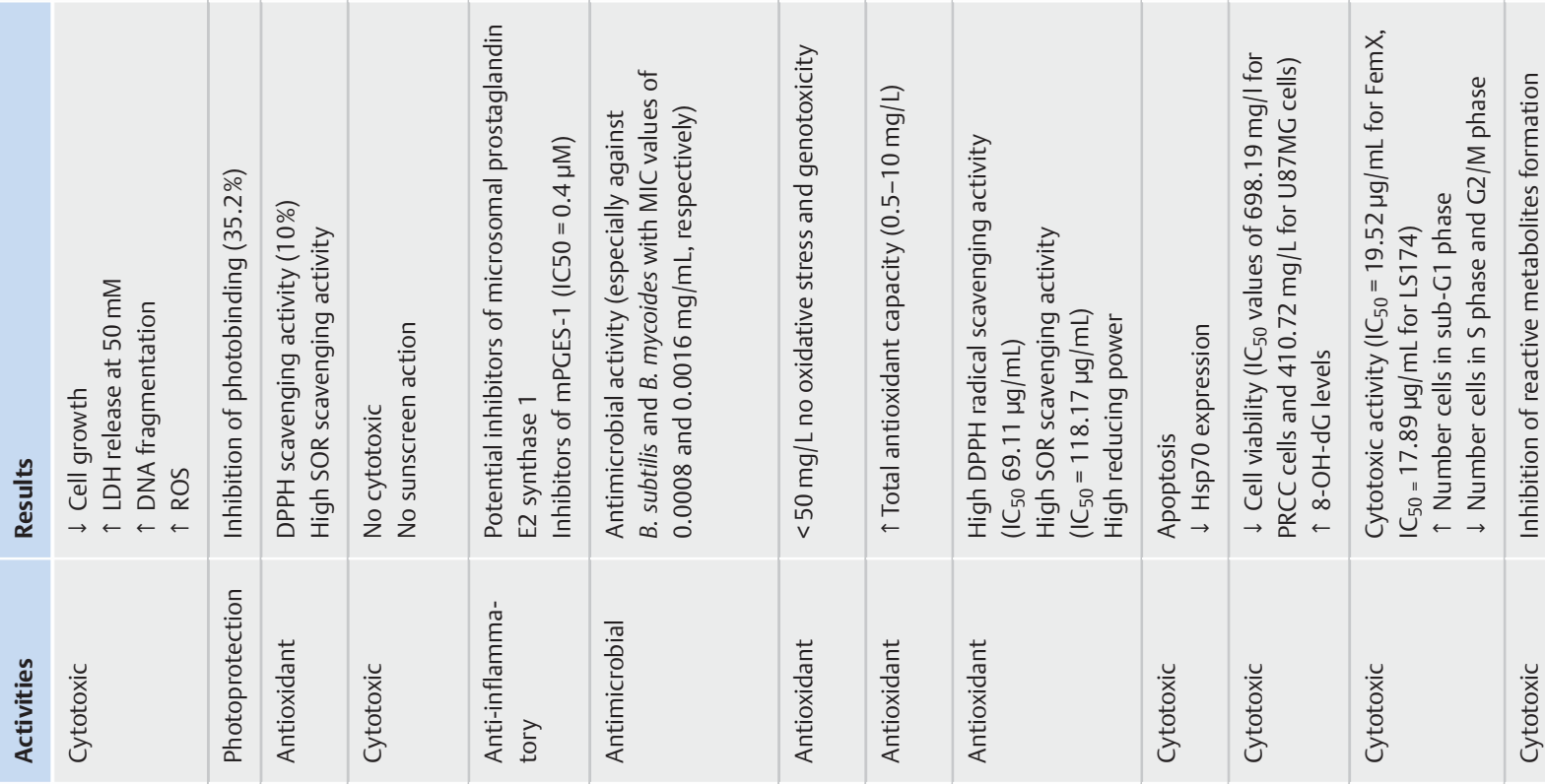

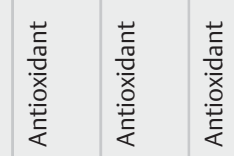
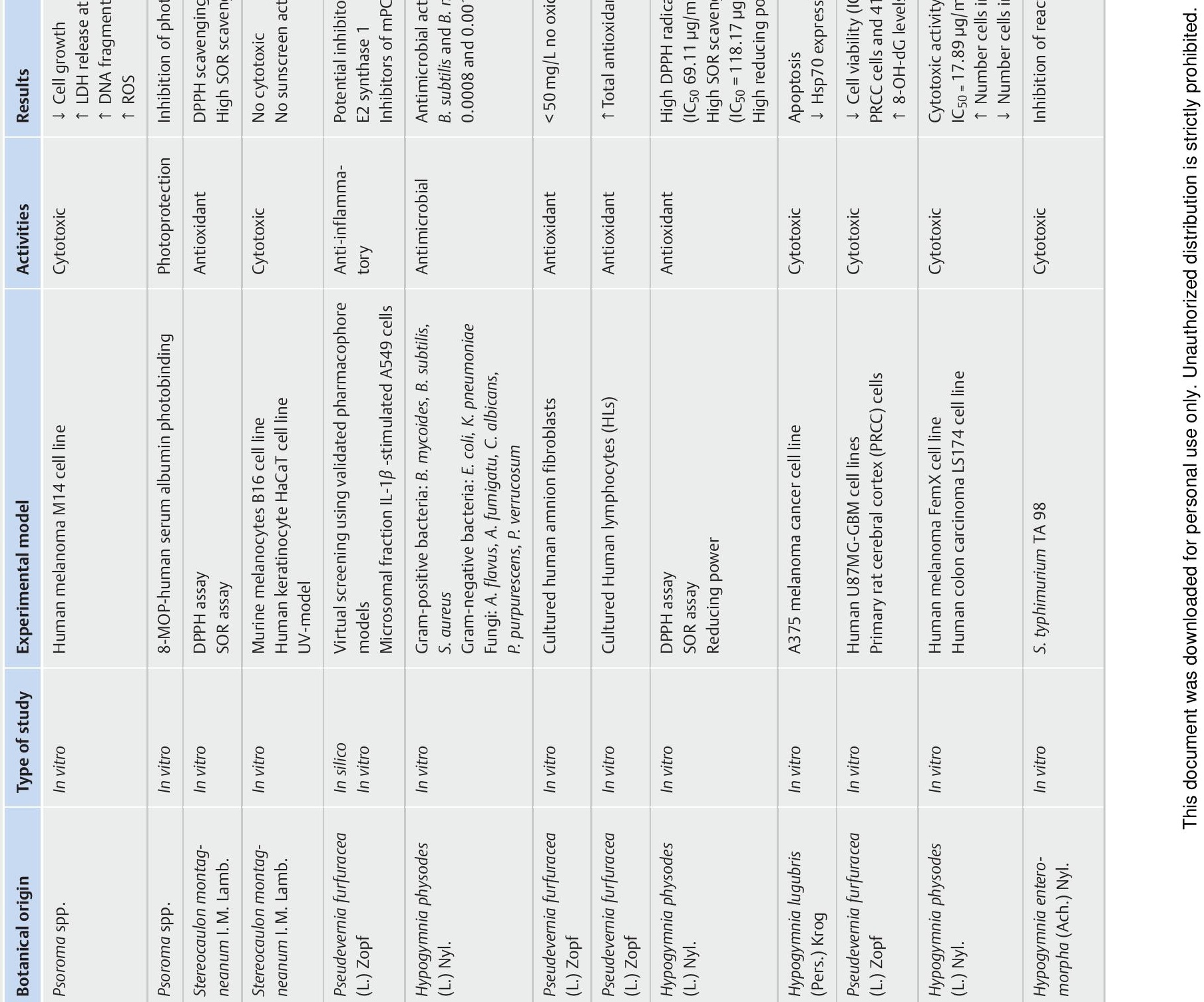

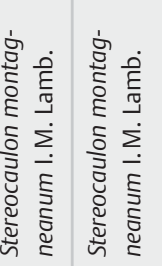

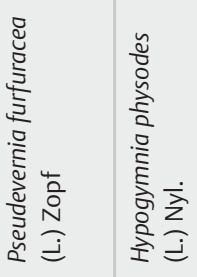

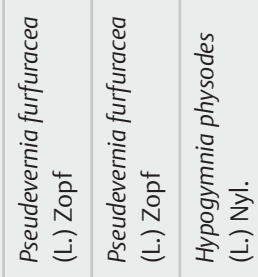
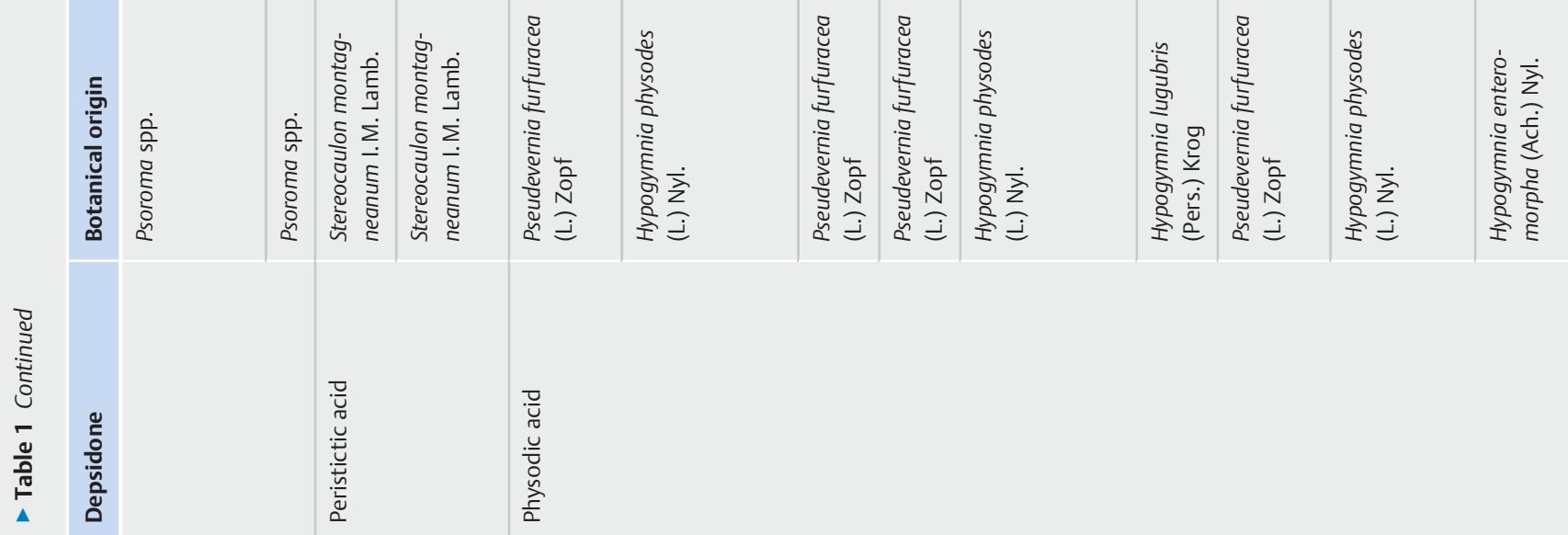


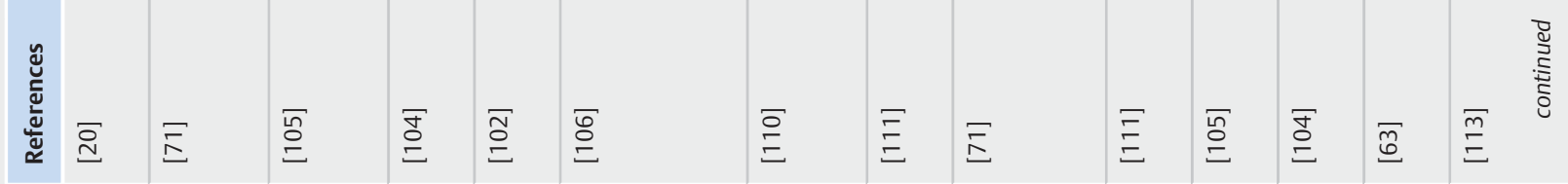
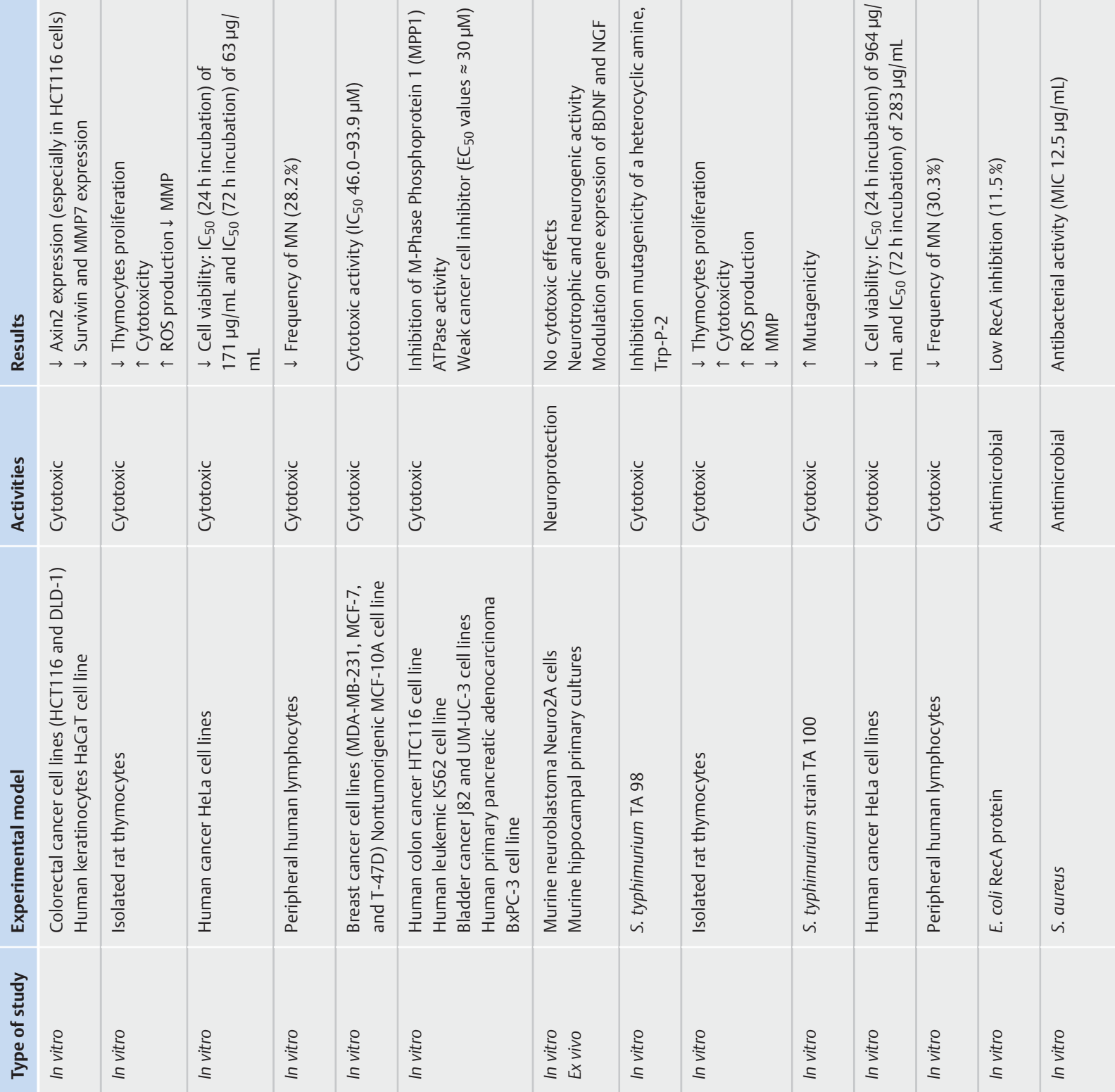

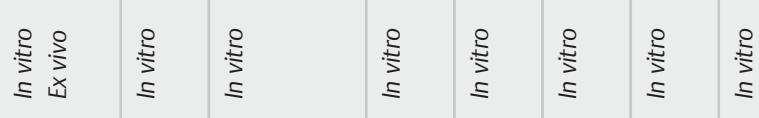

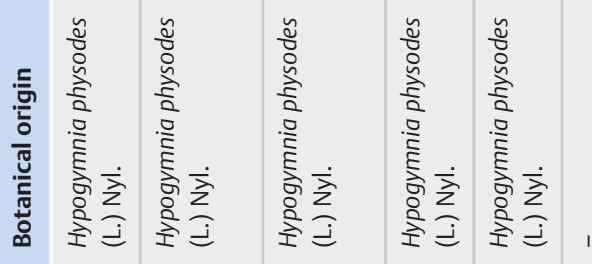
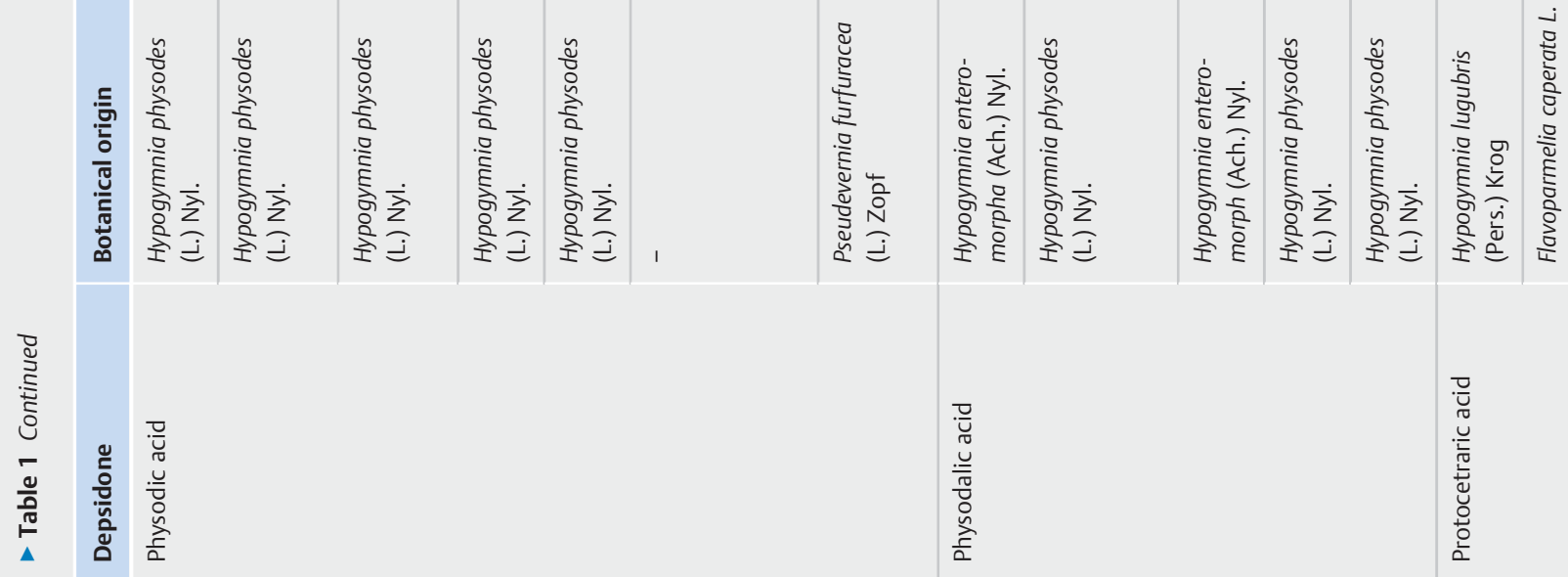


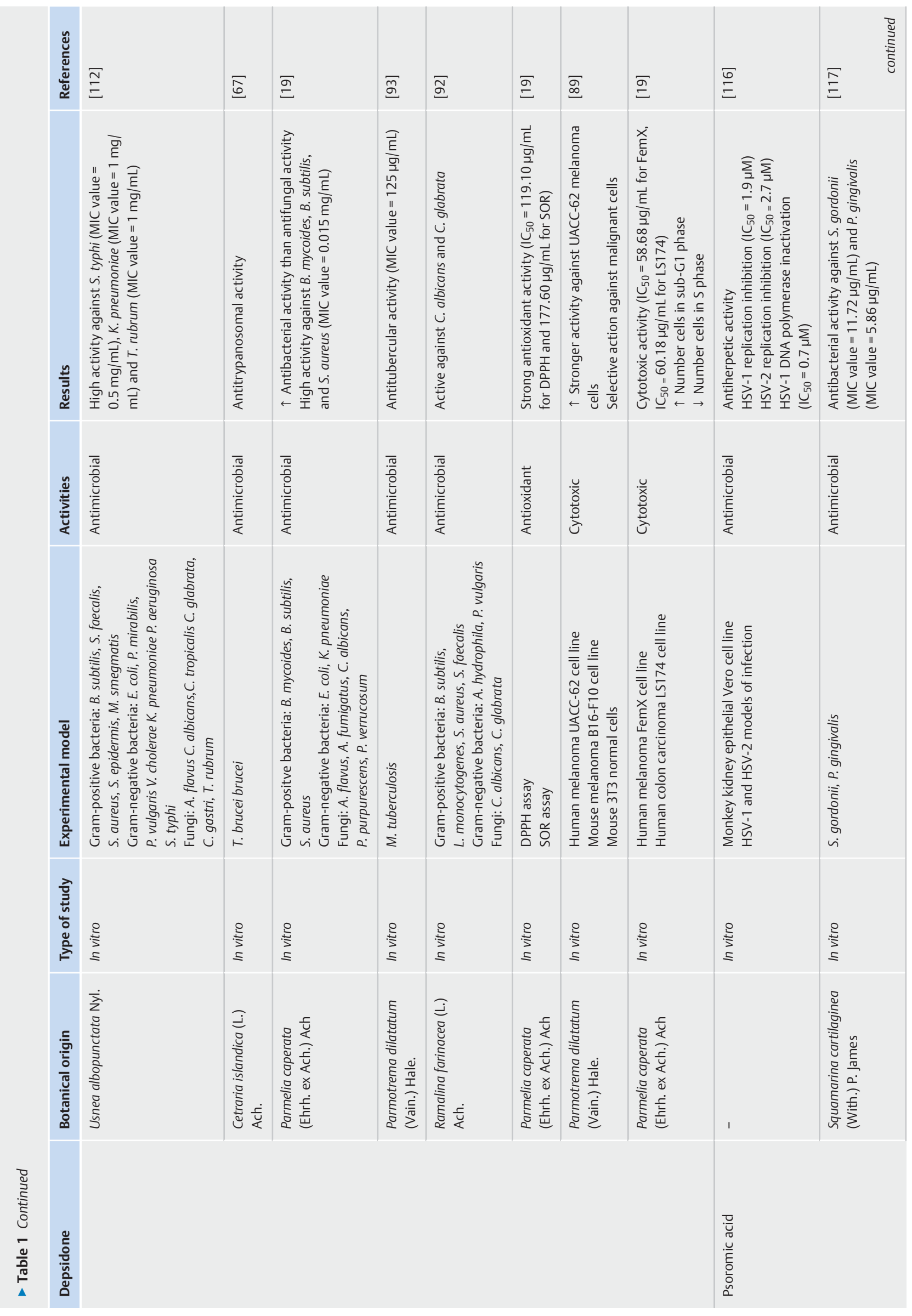



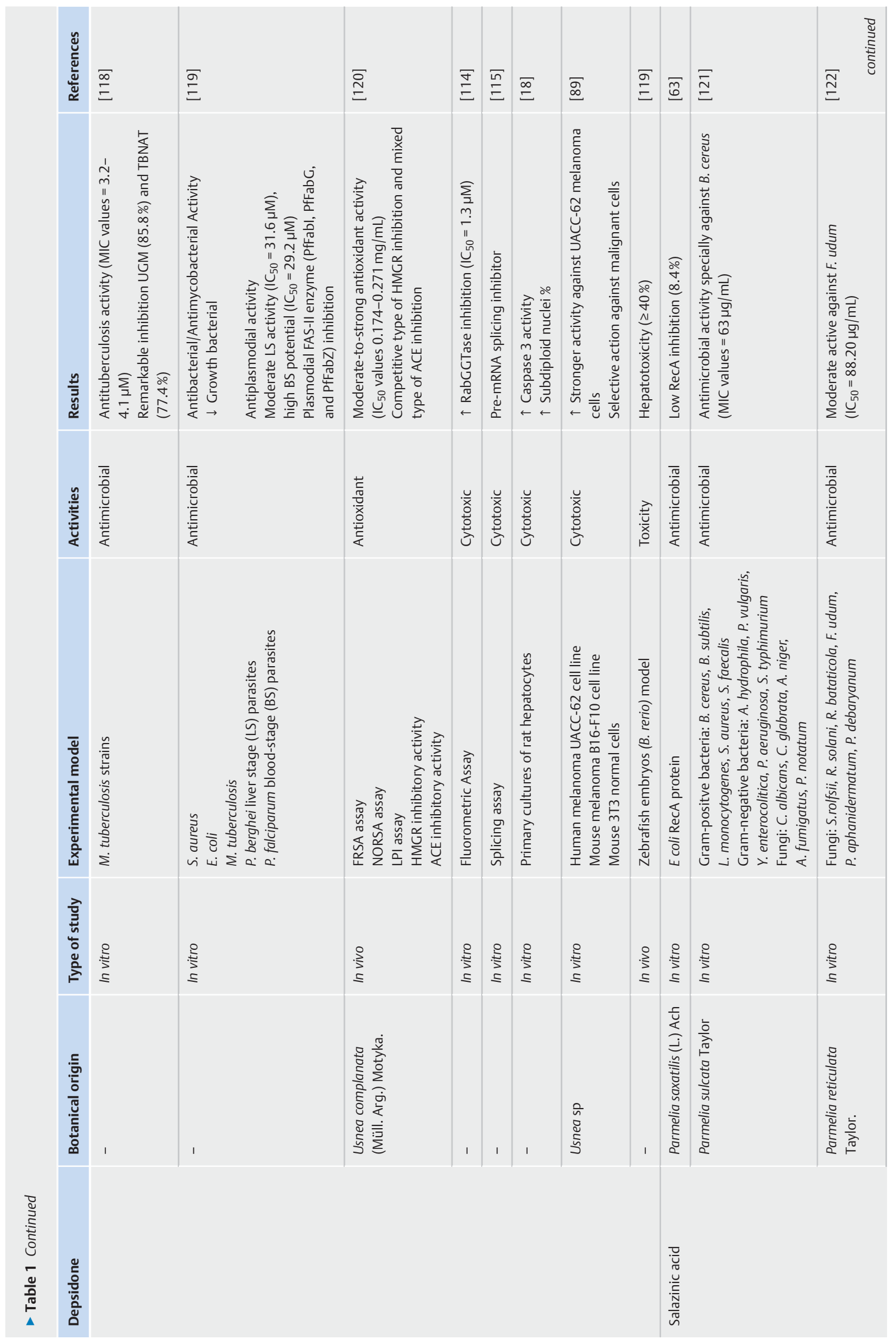


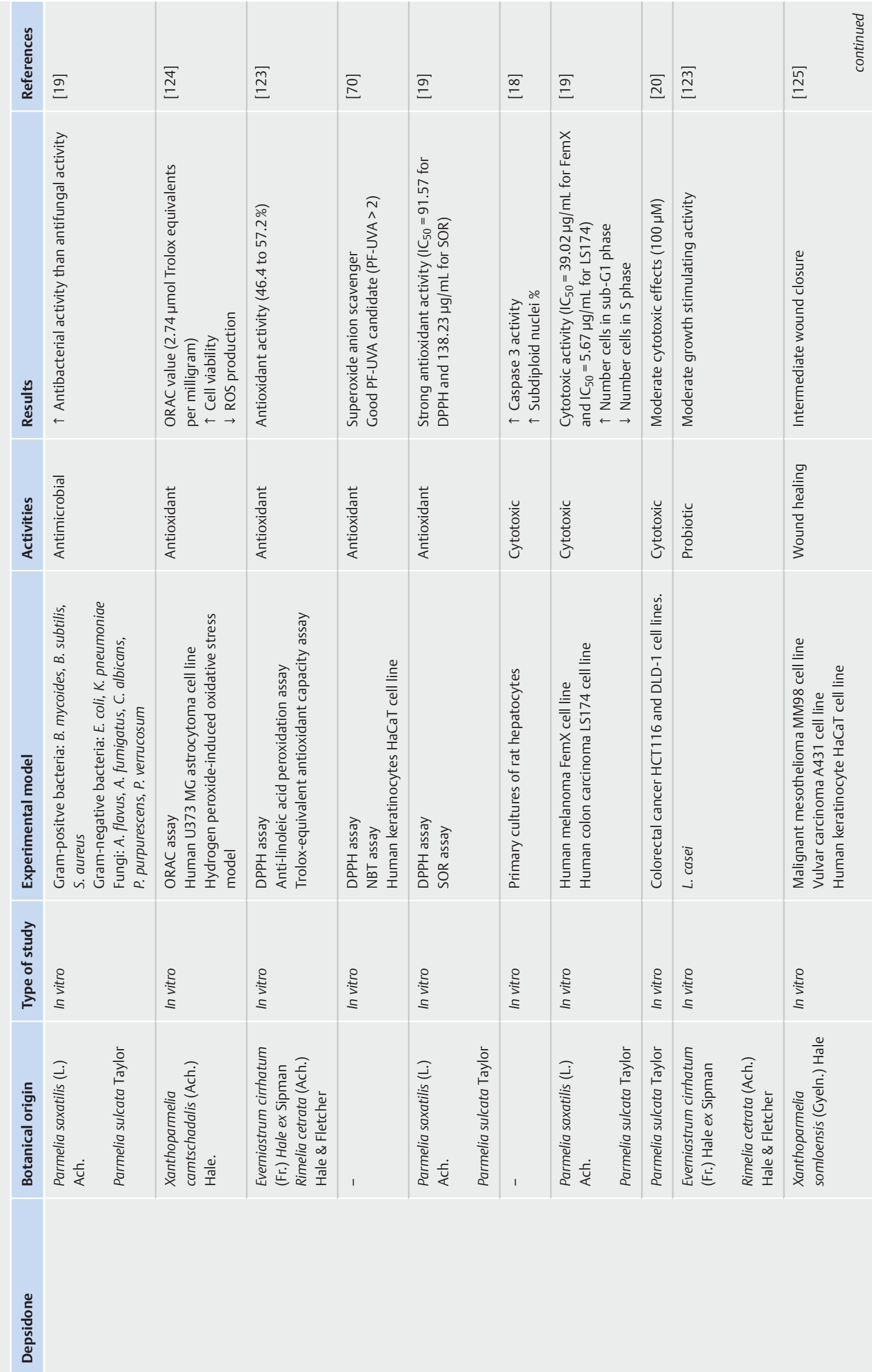

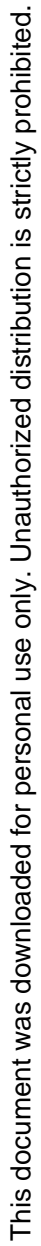


莺
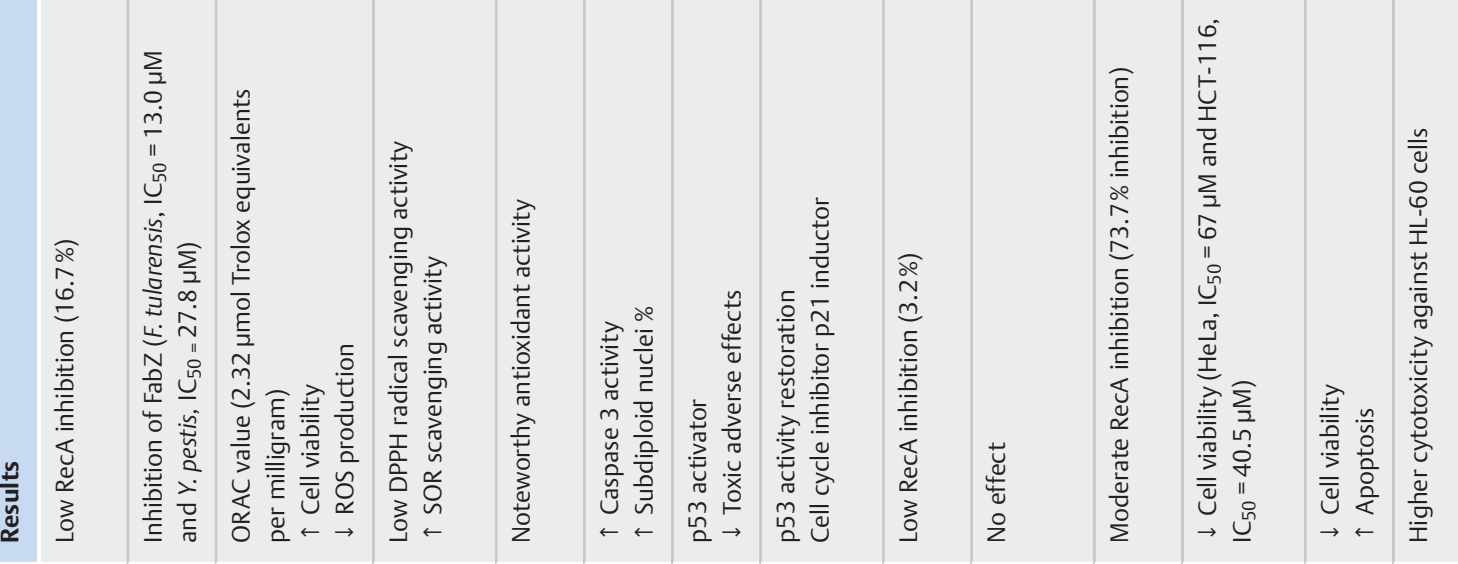

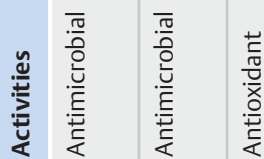

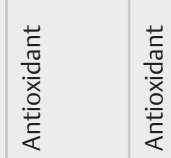

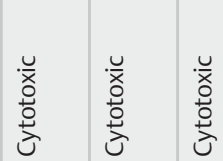

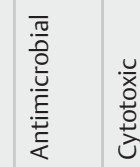
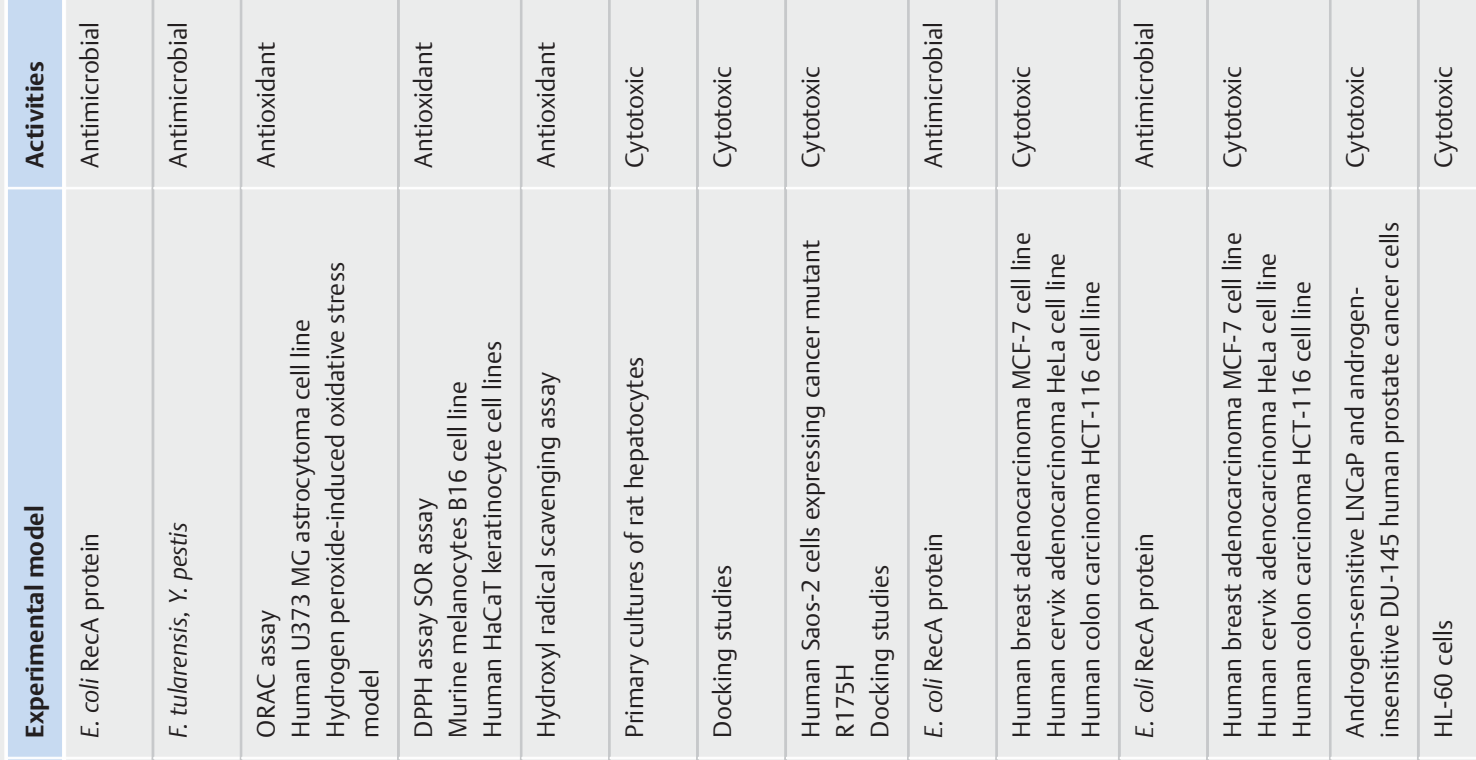

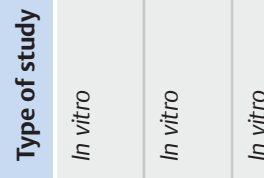

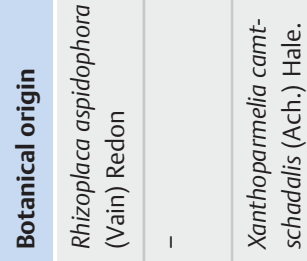

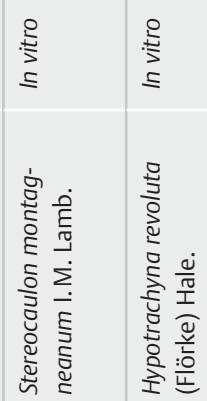

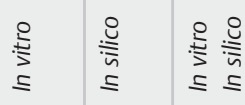

$\stackrel{8}{\stackrel{8}{5}}$

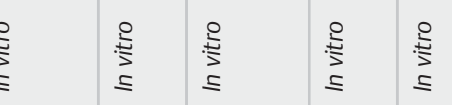
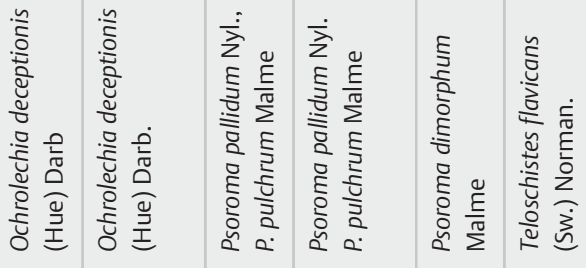

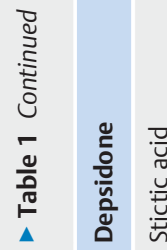


Lobaric acid showed high inhibition of PTP1B with an $\mathrm{IC}_{50}$ value of $0.87 \mu \mathrm{M}[80,81]$. Tyrosine phosphatase protein is overexpressed in insulin-resistant states [80]. Indeed, Klaman et al. showed that PTP-1B regulates energy balance, insulin sensitivity, and body fat stores in in vivo studies [58].

Lobaric acid could inhibit inflammation in LPS-activated macrophages through regulation of NF-KB/MAPK pathways, NLRP3 inflammasome activation, proinflammatory cytokines suppression (TNF- $\alpha$, IL-1, IL-6, and IL-18), and NO production inhibition [59, 60]. Moreover, lobaric acid reduced IL-8 expression and targeted PAR2 in an in vitro SLIGKV-NH $\mathrm{N}_{2}$-induced atopic dermatitis model in $\mathrm{HaCaT}$ keratinocytes [82]. Additionally, lobaric acid exerted antiinflammatory activity by inhibiting NF-KB and MAPK signaling pathways in TNF- $\alpha$-stimulated mouse vascular smooth muscle cells [83]. Furthermore, lobaric acid turned out to be a potent arachidonate-5-lipoxygenase inhibitor $\left(\mathrm{IC}_{50}\right.$ value of $\left.7.3 \mu \mathrm{M}\right)$ [84].

Lobaric acid also showed antimicrobial activity against bacteria and viruses. Thus, this depsidone inhibited RecA from E. coli by noncompetitively binding the ATP site [63]. While it showed moderate activity against Mycobacterium aurum [85], the activity against methicillin-resistant clinical isolates strains of $S$. aureus with an MIC $_{90}$ value of $64 \mu \mathrm{g} / \mathrm{mL}$ was good [62]. Moreover, lobaric acid showed anti-alphaviral activity against Chikungunya virus via NsP1 GTP binding and guanylation inhibition in hamster BHK21 and human Huh 7 cell lines [56]. Furthermore, binding studies of Nsp1 from SARS-CoV-2, a nonstructural protein 1 related to viral processes as viral replication and translation regulation, showed greater binding affinities with lobaric acid [86].

Other assayed activities were its antioxidant activity (superoxide radical scavenging action with $\mathrm{IC}_{50}$ value of $97.9 \mu \mathrm{mol}$ ) [87] and muscle relaxant as evidenced in the reduction of spontaneous muscle contractile activity in guinea-pig taenia coli [88].

\section{Norstictic acid}

The cytotoxic and antitumor role of norstictic acid has been evaluated in diverse in vitro (using different cancer cell lines) and in vivo models. Therefore, this compound has been shown to be effective for breast cancer treatment and prevention by targeting the c-Met signaling pathway and by suppressing the MDAMB-231/GFP tumor growth in mammary cancer cells and breast cancer xenograft models in athymic nude mice [52]. Moreover, norstictic acid exerted a noticeable cytotoxic effect against different human melanoma cell lines (FemX, UACC-62, and B16-F10) $[89,90]$ by increasing apoptotic cells in the sub-G1 phase [89]. Contrary, other studies reported that norstictic acid was not cytotoxic for melanocyte cells [91].

Concerning its antimicrobial activity, norstictic acid showed low to moderate antibacterial and antifungal action against a wide range of Gram-positive bacteria, Gram-negative bacteria, and fungi $[63,90,92,93]$. For instance, norstictic acid inhibited Mycobacterium tuberculosis growth with a MIC value of $62.5 \mu \mathrm{g} / \mathrm{mL}$ [93] and $E$. coli with a value of $18.2 \%$ [63].

Norstictic acid has also been shown to be a promising antioxidant agent against superoxide anion. On the other hand, its DPPH radical scavenging activity is not entirely clear, since its activity is contradictory in published works $[90,91]$.

\section{Pannarin}

Pannarin was able to inhibit the growth of the human melanoma M14 cell line and the human prostatic epithelial DU-145 cell line. Its cytotoxic activity has been related to oxidative stress induction as evidenced in ROS overproduction and DNA fragmentation [94, 95]. Moreover, pannarin showed cytotoxic activity against blood cells through a mechanism of hemolysis [96, 97].

Regarding antimicrobial activity, pannarin acted as bactericidal against methicillin-resistant S. aureus, and it also had a low capacity to inhibit $E$. coli RecA protein [63,97]. Moreover, pannarin was effective as an antiparasitic agent against promastigote forms of Leishmania spp [98].

Pannarin also showed antioxidant properties as evidenced in its superoxide radical scavenging capacity and NO-induced DNA damage [95], and it has photoprotector capacity (35.2\%) [99].

\section{Physodic acid}

There are several studies on the cytotoxic activity of physodic acid against different cancer and nontumorigenic cell lines from diverse origins (human or animal). Against A375 melanoma cancer cell line, physodic acid exhibited good cytotoxicity via apoptosis with a concentration-response relationship (range 6.25-50 $\mu \mathrm{M}$ ), showing inhibition of Hsp70 expression [100]. Other studies on FemX and LS174 cell lines revealed significant cytotoxic activity (IC 50 value of $19.52 \mu \mathrm{g} / \mathrm{mL}$ for FemX, IC 50 value of $17.89 \mu \mathrm{g} / \mathrm{mL}$ for LS174) with moderate proapoptotic activity. The number of cells in the sub-G1 phase increased, and the number of cells in the $S$ phase and G2/M phase was lower, indicating a G0/G1 cell cycle arrest [101]. Moreover, physodic acid was cytotoxic on different breast cancer cell lines (MDA-MB-231, MCF-7, and T-47D) with $\mathrm{IC}_{50}$ values that ranged from 46.0 to $93.9 \mu \mathrm{M}$ [102]. Physodic acid displayed weak cytotoxic activity on human U87MG-GBM cell lines and primary rat cerebral cortex (PRCC) cells (IC 50 value of $698.19 \mathrm{mg} / \mathrm{mL}$ for PRCC cells and IC $\mathrm{C}_{50}$ value of $410.72 \mathrm{mg} / \mathrm{mL}$ for U87MG cells) [103]. Moreover, physodic acid reduced thymocyte proliferation-induced cytotoxicity via oxidative stress mainly through ROS production [71]. On lymphocytes, this depsidone significantly decreased micronucleus frequency (28.2\%) compared to the positive control [104]. Furthermore, this compound proved to significantly reduce human cancer HeLa cell viability $\left(\mathrm{IC}_{50}[24 \mathrm{~h}]\right.$ value of $171 \mu \mathrm{g} / \mathrm{mL}$ and $\mathrm{IC}_{50}$ [72 h] value of $63 \mu \mathrm{g} /$ $\mathrm{mL}$ ) [105]. In another study, Talapatra et al. concluded that physodic acid was a weak cancer cell inhibitor $\left(\right.$ EC $_{50}$ values $\approx 30 \mu \mathrm{M}$ ) on multiple cancer cell lines (human colon cancer HTC116 cell line, human leukemic K562 cell line, bladder cancer J82 and UM-UC-3 cell lines, and human primary pancreatic adenocarcinoma BxPC-3 cell line) [106]. Physodic acid was studied as a modulator of $\beta$-catenin-dependent transcription on colorectal cancer (HCT116 and DLD-1). $\beta$-catenin transcription is related to cell survival and proliferation. Physodic acid reduced Axin2 ( $\beta$-catenin target gene) expression (especially in HCT116 cells) and decreased survivin and MMP7 expression [20]. Also, this depsidone was probed as an inhibitor of MPP1, essential for the cytokinesis process, indicating noncompetitive ATP binding in in silico studies [106].

Antimicrobial activity was also examined in bacteria and fungi. Physodic acid had strong inhibitory capacity especially against 
B. subtilis and B. mycoides with MIC values of 0.0008 and $0.0016 \mathrm{mg} / \mathrm{mL}$, respectively [101].

In addition to cytotoxic and antimicrobial properties, in vitro and in silico models showed the anti-inflammatory activity of physodic acid. Virtual screening evaluation revealed that this depsidone inhibits microsomal prostaglandin E2 synthase-1 [107]. Determination of mPGES-1 inhibition was performed using a microsomal fraction of IL- $1 \beta$-stimulated A549 cells $\left(\mathrm{IC}_{50}=0.43 \mu \mathrm{M}\right)$ [107].

Physodic acid was also investigated as an antioxidant agent, showing high DPPH radical scavenging activity $\left(\mathrm{IC}_{50}\right.$ value of $69.11 \mu \mathrm{g} / \mathrm{mL}$ ), high SOR scavenging activity (IC 50 value of $118.17 \mu \mathrm{g} / \mathrm{mL}$ ), and high reducing power [101]. Lower concentrations of physodic acid tested in cultured human amnion fibroblasts (<50 mg/L) and cultured human lymphocytes $(0.5-10 \mathrm{mg} /$ L) showed antioxidant capacities [108, 109].

Moreover, physodic acid showed neuroprotective properties, exhibiting neurotrophic and neurogenic activity via modulation of gene expression of BDNF and NGF in ex vivo (murine hippocampal primary cultures) and in vivo (murine neuroblastoma Neuro2A cells) assays [110].

\section{Physodalic acid}

Cytotoxic activity of physodalic acid is also described. However, compared to physodic acid, physodalic presented weaker activity. Physodalic acid demonstrated a weak reduction of viability $\left(\mathrm{IC}_{50}\right.$ [24 h] value of $964 \mu \mathrm{g} / \mathrm{mL}$ and $\mathrm{IC}_{50}[72 \mathrm{~h}$ ] value of $283 \mu \mathrm{g} / \mathrm{mL}$ ) on human cancer HeLa cell lines [105].

This compound also diminished the proliferation of thymocytes inducing cytotoxicity via ROS production. Physodalic acid reduced the frequency of micronucleus $(30.3 \%$ ) on lymphocytes $[71,104]$.

Despite being reported as mutagenic in S. typhimurium TA 100 [83], physodalic acid inhibited the mutagenicity of a heterocyclic amine, Trp-P-2, in S. typhimurium TA 98 [111].

\section{Protocetraric acid}

Most of the studies on protocetraric acid referred to its antimicrobial activity. Particularly, this depsidone inhibited pathogenic bacteria growth such as S. aureus (MIC value of $12.5 \mu \mathrm{g} / \mathrm{mL}$ ), M. tuberculosis (MIC value of $125 \mu \mathrm{g} / \mathrm{mL}$ ), S. typhi (MIC value of $0.5 \mathrm{mg} / \mathrm{mL}$ ), K. pneumoniae (MIC value of $1 \mathrm{mg} / \mathrm{mL}$ ), and $B$. mycoides, B. subtilis, and S. aureus (MIC value of $0.015 \mathrm{mg} / \mathrm{mL}$ ) [19, $93,112,113]$. Moreover, protocetraric acid revealed a marked antifungal activity against $T$. rubrum (MIC value of $1 \mathrm{mg} / \mathrm{mL}$ ), C. albicans, and C. glabrata (MIC value of $3.9 \mu \mathrm{g} / \mu \mathrm{l})[92,112]$. Furthermore, protocetraric acid showed trypanocidal activity against T. brucei brucei with a MIC value of $6.30 \mu \mathrm{M}$ [67].

Protocetraric acid also demonstrated cytotoxic activity against melanomas cell lines ( IC $_{50}$ values of $0.52 \mu \mathrm{g} / \mathrm{mL}$ for UACC- 62 cells and $58.68 \mu \mathrm{g} / \mathrm{mL}$ for FemX cells) and colon carcinoma cell line (IC 50 value of $60.18 \mu \mathrm{g} / \mathrm{mL}$ for LS174 cells) $[19,89]$.

This depsidone had also an effective antioxidant action as evidenced in DPPH and superoxide anions radical scavenging activity [19].

\section{Psoromic acid}

Psoromic acid presented an inhibitory effect against melanoma cell lines (UACC-62 and B16-F10) and primary cultures of rat hepatocytes $[18,89]$. The cytotoxic activity of psomoric acid was related to its capacity to induce an apoptotic response and to inhibit splicing and Rab GTPase $[18,114,115]$.

Psoromic acid was also of interest as an antiviral agent, as it blocked HSV-1 and HSV-2 replication and DNA synthesis [116]. Moreover, this depsidone reduced bacterial growth of Streptococcus gordonii (MIC value of $11.72 \mu \mathrm{g} / \mathrm{mL}$ ), Porphyromonas gingivalis (MIC value of $5.86 \mu \mathrm{g} / \mathrm{mL}$ ), and M. tuberculosis strains (3.2$4.1 \mu \mathrm{M})$ [116-118]. Furthermore, psoromic acid acts as an inhibitor of Plasmodium liver stages targeting the plasmodial FAS-II pathway [119]. In vivo studies determined that psoromic acid was hepatotoxic in fabp10a: DsRed2 zebrafish larvae ( $\geq 40 \%$ ) [119].

Using different in vitro antioxidant assays, Behera et al. revealed that psomoric acid had moderate to strong antioxidant activity [120].

\section{Salazinic acid}

Salazinic acid displayed cytotoxic activity against colorectal cancer cell lines (HCT116, DLD-1, and LS174), melanoma cancer cell lines (FemX), and primary cultures of rat hepatocytes by inducing apoptosis and cell cycle arrest [18-20].

Considering its antimicrobial activity, salazinic acid inhibited B. mycoides and B. subtilis growth with a MIC value of $0.0008 \mu \mathrm{g} /$ $\mathrm{m}$ and $B$. cereus with a MIC value of $63 \mu \mathrm{g} / \mathrm{mL}[19,121]$. However, this depsidone was ineffective as an $E$. coli Rec A protein inhibitor [63]. Moreover, salazinic acid showed moderate antifungal activity against Fusarium udum ( $\mathrm{IC}_{50}$ value of $88.20 \mu \mathrm{g} / \mathrm{mL}$ ) [122]. Furthermore, this compound promoted growth effects on probiotic bacteria Lactobacillus casei [123].

Salazinic acid has also turned out to be interesting as an antioxidant compound as revealed in different in vitro assays (DPPH assay, SOR assay, ORAC assay) $[19,70,123,124]$ Because of its antioxidant properties, this depsidone increased cell viability and reduced ROS production in a hydrogen peroxide-induced oxidative stress model in the human U373 MG astrocytoma cell line [124]. Moreover, salazinic acid proved to protect against UVA sunrays (PF-UVA > 2) [70].

Another property attributed to salazinic action is its ability to heal wounds on HaCaT keratinocytes [125].

\section{Stictic acid}

Stictic acid has been investigated for its antioxidant, antimicrobial, and cytotoxic properties. This promising compound showed antioxidant activity in diverse in vitro test models. Despite its low DPPH radical scavenging activity (less than $10 \%$ ), stictic acid exhibited moderate ORAC values $(2.32 \mu \mathrm{molTE} / \mathrm{mg})$, high SOR scavenging activity $\left(\mathrm{IC}_{50}\right.$ value of $\left.35 \mu \mathrm{M}\right)$, and good hydroxyl radical scavenging activity (7.63 Trolox equivalents) $[91,124,126]$. Furthermore, in hydrogen peroxide-induced oxidative stress conditions, this depsidone protected human U373 MG astrocytoma cell line at 5,10 , and $25 \mathrm{~g} / \mathrm{mL}$ concentrations via inhibition of ROS production [124]. These findings showed that stictic acid may be a potential neuroprotective compound. 
On the other hand, cytotoxicity evaluation on murine melanocytes B16 cells and human HaCaT keratinocyte cell lines showed no safety; therefore, its possible cosmetic use was dismissed [91].

Enzymes involved in fatty acid biosynthesis processes such as FabZ are excellent targets for developing broad-spectrum antibiotics. Differences between FAS systems (bacterial and human) imply that the inhibition process does not interfere with the host. Stictic acid exhibited a significant inhibitory effect against Francisella tularensis ( $\mathrm{IC}_{50}$ value of $\left.13 \mu \mathrm{M}\right)$ and Yersinia pestis ( $\mathrm{IC}_{50}$ value of $27 \mu \mathrm{M}) \beta$-hydroxyacyl-acyl carrier protein dehydratase (FabZ) [55]. Stictic acid's antimicrobial properties have been investigated, along with other depsidones through $E$. coli RecA protein inhibition. RecA is related to bacterial SOS response regulation, which is involved in resistance to antimicrobials. Stictic acid exhibited low RecA inhibition (16.7\%) [63].

In vitro and in silico assays reported cytotoxic activity of this compound. In human cancer, p53 genes mutate frequently. Using docking studies, stictic acid showed potential p53 reactivation by binding to a transiently open L1/S3 pocket of the $\mathrm{p} 53$ core domain [127]. In another study, stictic acid showed great potential as a p53 activator and less adverse effect but poor pharmacokinetic properties [128]. To support in silico assays, stictic acid was biologically evaluated in human Saos-2 cells expressing cancer mutant $\mathrm{R} 175 \mathrm{H}$, restoring $\mathrm{p} 53$ activity via induction of the cell cycle inhibitor p21 [127]. Moreover, stictic acid displayed cytotoxic activity in different cell lines. In primary cultures of rat hepatocytes, this depsidone showed significant concentration-dependent activation of caspase 3 and an increased percentage of subdiploid nuclei (DNA fragmentation) [18].

\section{Variolaric acid}

While variolaric acid was tested to evaluate its cytotoxic and antimicrobial activity, the viability assays reported no significant effect on human breast adenocarcinoma cell line MCF-7, human cervical adenocarcinoma cell line HeLa, and human colon carcinoma HCT-116 [76]. Moreover, this depsidone had a low capacity to inhibit E. coli RecA protein (3.2\%) [63].

\section{Vicanicin}

Cytotoxic activity of vicanicin was evaluated in different cell cancer lines, showing significant loss of viability in a concentrationdependent manner on human cervix adenocarcinoma HeLa cell lines and human colon carcinoma HCT-116 (IC 50 values of $67 \mu \mathrm{M}$ and $40.5 \mu \mathrm{M}$, respectively). However, vicanicin did not have effects on human breast adenocarcinoma MCF-7 cells. This depsidone neither exhibited antiradical activity nor reduced intracellular ROS level, dismissing both as the potential mechanism of cytotoxicity [76].

In the model of androgen-sensitive (LNCaP) and androgen-insensitive (DU-145) human prostate cancer cells, vicanicin decreased cell growth by the induction of apoptosis. The expression of Bcl-2, Bax, TRAIL, COX-2, NOS2, and Hsp70 proteins was analyzed, and the inhibition of Hsp70 proteins expression as a mediator of the process should be highlighted [129]. Moreover, this depsidone exhibited moderate activity against HL-60 cells as revealed on antileukemic assay [130]. Regarding its antimicrobial activity, this depsidone showed moderate inhibition of $E$. coli RecA protein (73\%) [63].

\section{Other Depsidones}

Many depsidones have been identified but barely studied. Computational studies have revealed that connorstictic acid, cryptostictic acid, conhypoprotocetraric acid, hypoprotocetraric acid, and gangaleoidin, among other depsidones, are potent hydroxyl and superoxide anion radical scavengers in polar environments [131]. Other stictic acid derivatives also displayed antioxidant activities such as peristictic acid and cryptostictic acid that showed weak DPPH radical scavenging activity (about 10\%) and potent superoxide anion radical scavenging activity equivalent to that of ascorbic acid. These compounds showed no cytotoxicity on B16 murine melanoma and HaCaT human keratinocyte cell lines $\left(\mathrm{IC}_{50}\right.$ higher than $\left.100 \mu \mathrm{M}\right)$ [91]. The compounds 8'-Omethylstictic and deoxystictic acid showed radical scavenging activity (61.85 and 13.176 Trolox equivalents, respectively) [126]. Moreover, 8'-O-methylstictic acted as a DPPH scavenger and had good properties for skin penetration (lipophilicity and permeability) [132].

These derivatives have also displayed other activities. For example, hypostictic acid showed antimicrobial properties due to its moderate inhibitory activity against $M$. tuberculosis (MIC value of $94 \mu \mathrm{g} / \mathrm{mL}$ ) [93]. The compound $8^{\prime}$-O-ethylstictic presented moderate cytotoxicity against human epithelial carcinoma HeLa, human lung cancer $\mathrm{NCl}-\mathrm{H} 460$, liver hepatocellular carcinoma HepG2, and human breast cancer MCF-7 cell lines [133].

Other depsidones recently identified, such as ceratinalone and flavicansone, isolated from Usnea ceratina Ach. and Teloschistes flavicans (Sw.) Norman, respectively, have also shown cytotoxic properties [130,133]. Ceratinalone has been tested against different cancer cell lines such as human epithelial carcinoma HeLa, human lung cancer $\mathrm{NCl}-\mathrm{H} 460$, liver hepatocellular carcinoma HepG2, and human breast cancer MCF-7. It acted as a moderate cytotoxic agent [133]. On the other hand, flavicansone exhibited cytotoxic activity as evidenced in an antileukemic assay against HL-60 cells (IC 50 value of $58 \mu \mathrm{M})$ [130].

\section{Conclusions and Future Perspectives}

Indeed, lichens produce unique bioactive secondary metabolites such as depsidones. Most pharmacological studies of depsidones focus on fumarprotocetraric acid, lobaric acid, norstictic acid, physodic acid, salazinic acid, and stictic acid compounds. Lichen depsidones have proven their ability to perform diverse biological activities, with cytotoxic, antimicrobial, and antioxidant the most studied. While many published works are on in vitro studies, the in vivo studies are very limited, and no clinical trials are yet available.

The cytotoxic activity has been evaluated against different cell lines of animal and human origin. Most of these works on cytotoxic activity are based on assessing their effect on cell viability, however, there are fewer studies that clarify the molecular targets and signaling pathways. The most interesting depsidones with cytotoxic activity included lobaric and physodic acids. Regarding the antimicrobial activity, most of the studies evaluated antibacterial 
activity against both Gram-positive bacteria and Gram-negative bacteria and fungi, mainly Candida spp. Among depsidones, fumarprotocetraric and protocetraric acids are emphasized for their antimicrobial properties. The antioxidant activity has been investigated using techniques such as the DPPH method and ORAC assay as well as in cellular and animal models of oxidative stress. The compounds salazinic acid and stictic acid stand out for their antioxidant properties.

Our study revealed that the future perspectives of pharmacological research on depsidones should focus on:

1. Deepening the activities for these depsidones, clarifying the mechanism of action.

2. Evaluating other and novel potential actions and properties of depsidones.

3. Investigating the potential therapeutic activity of unstudied depsidones from a pharmacological perspective as notatic acid, nortotatic acid, constictic acid, and diploicin.

4. Performing more in vivo studies confirming the activity shown in in vitro studies.

5. Conducting clinical trials for those depsidones that have shown potential pharmacological activities.

\section{Contributors' Statement}

Data collection: I.M. Ureña-Vacas, E. González-Burgos; drafting the manuscript: I. M. Ureña-Vacas, E. González-Burgos; critical revision of the manuscript: P. K. Divakar, M.P. Gómez-Serranillos.

\section{Acknowledgements}

This study was supported by the Spanish Ministry of Science, Innovation, and Universities (PID2019-105312GB-100) and the Santander-University Complutense of Madrid (PR87/19-22637). I. Ureña-Vacas is supported by a grant CT42/18-CT43/18 from Complutense University of Madrid for predoctoral research.

\section{Conflict of Interest}

The authors declare that they have no conflict of interest.

\section{References}

[1] Aschenbrenner IA, Cernava T, Berg G, Grube M. Understanding microbial multi-species symbioses. Front Microbiol 2016; 7: 180. doi:10.3389/fmicb.2016.00180

[2] Calcott M], Ackerley DF, Knight A, Keysers RA, Owen JG. Secondary metabolism in the lichen symbiosis. Chem Soc Rev 2018; 47: 17301760. doi:10.1039/c7cs00431a

[3] Ivanova D, Ivanov D. Ethnobotanical use of lichens: lichens for food review. Scr Sci Med 2009; 41: 11. doi:10.14748/ssm.v41i1.456

[4] Singh H, Husain T, Agnihotri P, Pande PC, Khatoon S. An ethnobotanical study of medicinal plants used in sacred groves of Kumaon Himalaya, Uttarakhand, India. J Ethnopharmacol 2014; 154: 98-108. doi:10.1016| j.jep.2014.03.026

[5] Devkota S, Chaudhary R, Werth S, Scheidegger C. Indigenous knowledge and use of lichens by the lichenophilic communities of the Nepal Himalaya. J Ethnobiol Ethnomed 2017; 13: 1-10. doi:10.1186/s13002017-0142-2
[6] Molnár K, Farkas E. Current results on biological activities of lichen secondary metabolites: A review. Z Naturforsch C J Biosci 2010; 65: 157173. doi:10.1515/znc-2010-3-401

[7] Furmanek $\measuredangle$, Czarnota P, Seaward MRD. Antifungal activity of lichen compounds against dermatophytes: a review. J Appl Microbiol 2019; 127: 308-325. doi:10.1111/jam.14209

[8] Rankovic B, Kosanic M. Lichens as a Potential Lichen Source of bioactive secondary Metabolites. In: Rankovic B, ed. Lichen secondary Metabolites. Bioactive Properties and pharmaceutical Potential. Cham, Switzerland: Springer International; 2015: 1-26

[9] Nash TH, Ryan BD, Gries C, Bungartz F. Lichen Flora of the greater Sonoran Desert Region. Dexter, MI: Arizona State University, Thomasshore, Inc.; 2002

[10] Fernández-Moriano C, Gómez-Serranillos MP, Crespo A. Antioxidant potential of lichen species and their secondary metabolites. A systematic review. Pharm Biol 2016; 54: 1-17. doi:10.3109/13880209.2014. 1003354

[11] Solárová Z, Liskova A, Samec M, Kubatka P, Büsselberg D, Solár P. Anticancer potential of lichens' secondary metabolites. Biomolecules 2020; 10: 87. doi:10.3390/biom10010087

[12] Piovano M, Garbarino JA, Giannini FA, Correché ER, Feresin G, Tapia A, Zacchino S, Enriz RD. Evaluation of antifungal and antibacterial activities of aromatic metabolites from lichens. Bol Soc Chil Quím 2002; 47: 235240. doi: $10.4067 /$ S0366-16442002000300006

[13] Podterob A. Chemical composition of lichens and their medical applications. Pharm Chem J 2008; 42: 582-588. doi:10.1007/s11094-0090183-5

[14] Shukla V, Joshi GP, Rawat MSM. Lichens as a potential natural source of bioactive compounds: A review. Phytochem Rev 2010; 9: 303-314. doi:10.1007/s11101-010-9189-6

[15] Vickery ML, Vickery B. Polyketides. In: Secondary Plant Metabolism. London: MacMillan Press; 1981: 88-111

[16] Legaz M, de Armas R, Vicente C. Bioproduction of Depsidones for pharmaceutical Purposes. In: Rundfeldt C, ed. Drug Development-A case Study based Insight into modern Strategies. InTech; 2011. doi:10.5772/ 27051. Accessed November 1, 2020 at: http://www.intechopen.com/ books/drug-development-a-case-study-based-insight-into-modernstrategies/bioproduction-of-depsidones-for-pharmaceutical-purposes

[17] Ibrahim SRM, Mohamed GA, Al Haidari RA, El Kholy AA, Zayed MF, Khayat MT. Biologically active fungal depsidones: chemistry, biosynthesis, structural characterization, and bioactivities. Fitoterapia 2018; 129 : 317-365. doi:10.1016/j.fitote.2018.04.012

[18] Correché ER, Enriz RD, Piovano M, Giannini F, Garbarino J, Enriz D. Cytotoxic and apoptotic effects on hepatocytes of secondary metabolites obtained from lichens. Altern Lab Anim 2004; 32: 605-615. doi:10.1177| 026119290403200611

[19] Manojlović N, Ranković B, Kosanić M, Vasiljević P, Stanojković T. Chemical composition of three Parmelia lichens and antioxidant, antimicrobial and cytotoxic activities of some their major metabolites. Phytomedicine 2012; 19: 1166-1172. doi:10.1016/j.phymed.2012.07.012

[20] Paluszczak J, Kleszcz R, Studzińska-Sroka E, Krajka-Kuźniak V. Lichen-derived caperatic acid and physodic acid inhibit Wnt signaling in colorectal cancer cells. Mol Cell Biochem 2018; 441: 109-124. doi:10.1007| s11010-017-3178-7

[21] Honegger R. Lichen-forming Fungi and their Photobionts. In: Deising HB ed. Plant Relationships. The Mycota (A comprehensive Treatise on Fungi as experimental Systems for basic and applied Research). Berlin: Springer; 2009: 307-333. doi:10.1007/978-3-540-87407-2_16

[22] Brunauer G, Hager A, Grube M, Türk RM, Stocker-Wörgötter E. Alterations in secondary metabolism of aposymbiotically grown mycobionts of Xanthoria elegans and cultured resynthesis stages. Plant Physiol Biochem 2007; 45: 146-151. doi:10.1016/j.plaphy.2007.01.004 
[23] Elshobary ME, Osman ME, Abo-Shady AM, Komatsu E, Perreault $H$ Sorensen J, Piercey-Normore MD. Algal carbohydrates affect polyketide synthesis of the lichen-forming fungus Cladonia rangiferina. Mycologia 2016; 108: 646-656. doi:10.3852/15-263

[24] Díaz E, Zamora ], Ruibal C, Divakar PK, González-Benítez N, Le Devehat F, Chollet M, Ferron S, Sauvager A, Boustie J, Crespo A, Molina MC. Axenic culture and biosynthesis of secondary compounds in lichen symbiotic fungi, the Parmeliaceae. Symbiosis 2020; 82: 1-15. doi:10.1007/ s13199-020-00719-3

[25] Gauslaa Y, Bidussi M, Solhaug KA, Asplund ], Larsson P. Seasonal and spatial variation in carbon based secondary compounds in green algal and cyanobacterial members of the epiphytic lichen genus Lobaria. Phytochemistry 2013; 94: 91-98. doi:10.1016/j.phytochem.2013.04.003

[26] Nguyen KH, Chollet-Krugler M, Gouault N, Tomasi S. UV-protectant metabolites from lichens and their symbiotic partners. Nat Prod Rep 2013; 30: 1490-1508. doi:10.1039/c3np70064j

[27] Stocker-Wörgötter E. Biochemical Diversity and Ecology of Lichen-forming Fungi: Lichen Substances, chemosyndromic Variation and Origin of Polyketide-Type Metabolites (biosynthetic Pathways). In: Upreti DK, Divakar PK, Shukla V, Bajpai R, eds. Recent Advances in Lichenology: Modern Methods and Approaches in Lichen Systematics and Culture Techniques, Volume 2. New Delhi: Springer; 2015: 161-180. doi:10.1007/978-81-322-2235-4_9

[28] Parrot D, Legrave N, Delmail D, Grube M, Suzuki M, Tomasi S. Review Lichen-associated bacteria as a hot spot of chemodiversity: Focus on uncialamycin, a promising compound for future medicinal applications. Planta Med 2016; 82: 1143-1152. doi:10.1055/s-0042-105571

[29] Hawksworth D, Grube M. Lichens redefined as complex ecosystems. New Phytol 2020; 227: 1281-1283. doi:10.1111/nph.16630

[30] Smith H, Dal Grande F, Muggia L, Keuler R, Divakar PK, Grewe F, Schmitt I, Thorsten Lumbsch H, Leavitt SD. Metagenomic data reveal diverse fungal and algal communities associated with the lichen. Symbiosis 2020; 82: 133-147. doi:10.1101/2020.03.04.966853

[31] Mosbach K. Biosynthesis of lichen substances, products of a symbiotic association. Angew Chem 1969; 8: 240-250. doi:10.1002/anie. 196902401

[32] Elix JA, Stocker-Wörgötter E. Biochemistry and secondary Metabolites. In: Thomas H Nash III, ed. Lichen Biology. 2nded. Cambridge: Cambridge University Press; 2008: 104-133. doi:10.1017/ CBO9780511790478.008

[33] Huneck S, Yoshimura I. Identification of Lichen Substances. Berlin-Heidelberg: Springer; 1996: 493

[34] Culberson CF. Joint occurrence of a lichen depsidone and its probable depside precursor. Science 1964; 143: 255-256. doi:10.1126/science. 143.3603.255

[35] Erdtman $\mathrm{HGH}$. The chemistry of forest, humic acids, lichens, lignans, lignins and conifers. Tappi 1962; 45: 14A, 16A, 18A, 20A, 26A, 28A, 30A, $34 \mathrm{~A}, 36 \mathrm{~A}, 38 \mathrm{~A}$

[36] Culberson WL, Culberson CF. The Lichen Genera Cetrelia and Platismatia (Parmeliaceae). Systematic Plant Studies. Contributions from the United States National Herbarium. Washington, DC: Smithsonian Institution Press; 1968: 449-558

[37] Culberson CF. A note on the chemical strains of Pseudevernia furfuracea. Bryologist 1965; 68: 435-439

[38] Elix JA, Jenie UA, Parker JL. A novel synthesis of the lichen depsidones divaronic acid and stenosporonic acid, and the biosynthetic implications. Aust J Chem 1987; 40: 1451-1464

[39] Stocker-Wörgötter E. Metabolic diversity of lichen-forming ascomycetous fungi: culturing, polyketide and shikimate metabolite production, and PKS genes. Nat Prod Rep 2008; 25: 188-200. doi:10.1039/ b606983p

[40] Schmitt I, Martín MP, Kautz S, Lumbsch HT. Diversity of non-reducing polyketide synthase genes in the Pertusariales (lichenized Ascomycota): a phylogenetic perspective. Phytochemistry 2005; 66: 1241-1253. doi:10.1016/j.phytochem.2005.04.014

[41] Armaleo D, Sun X, Culberson C. Insights from the first putative biosynthetic gene cluster for a lichen depside and depsidone. Mycologia 2011; 103: 741-754. doi:10.3852/10-335

[42] Bertrand RL, Abdel-Hameed M, Sorensen JL. Lichen biosynthetic gene clusters. Part I. Genome sequencing reveals a rich biosynthetic potential. J Nat Prod 2018; 81: 723-731. doi:10.1021/acs.jnatprod.7b00769

[43] Armaleo D, Müller O, Lutzoni F, Andrésson ÓS, Blanc G, Bode HB, Collart FR, Dal Grande F, Dietrich F, Grigoriev IV, Joneson S, Kuo A, Larsen PE, Logsdon JM Jr, Lopez D, Martin F, May SP, McDonald TR, Merchant SS, Miao V, Morin E, Oono R, Pellegrini M, Rubinstein N, Sanchez-Puerta MV, Savelkoul E, Schmitt I, Slot JC, Soanes D, Szövényi P, Talbot NJ, Veneault-Fourrey C, Xavier BB. The lichen symbiosis re-viewed through the genomes of Cladonia grayi and its algal partner Asterochloris glomerata. BMC Genom 2019; 20: 605. doi:10.1186/s12864-019-5629-x

[44] Pizarro D, Divakar PK, Grewe F, Crespo A, Dal Grande F, Lumbsch HT. Genome-wide analysis of biosynthetic gene cluster reveals correlated gene loss with absence of usnic acid in lichen-forming fungi. Genome Biol Evol 2020; 12: 1858-1868. doi:10.1093/gbe/evaa189

[45] Hunyadi A. The mechanism(s) of action of antioxidants: From scavenging reactive oxygen/nitrogen species to redox signaling and the generation of bioactive secondary metabolites. Med Res Rev 2019; 39: $2505-$ 2533. doi:10.1002/med.21592

[46] Manojlovic NT, Vasiljevic PJ, Maskovic PZ, Juskovic M, BogdanovicDusanovic G. Chemical composition, antioxidant, and antimicrobial activities of lichen Umbilicaria cylindrica (L.) Delise (Umbilicariaceae). Evid Based Complement Alternat Med 2012; 2012: 452431. doi:10.1155/2012/452431

[47] Williams D, Loganzo F, Whitney L, Togias J, Harrison R, Singh M, McDonald L, Chelvendran S, Andersen R. Depsides isolated from the Sri Lankan lichen Parmotrema sp. exhibit selective Plk1 inhibitory activity. Pharm Biol 2011; 49: 296-301. doi:10.3109/13880209.2010.517540

[48] Hong JM, Suh SS, Kim TK, Kim JE, Han SJ, Youn UJ, Yim JH, Kim IC. Anticancer activity of lobaric acid and lobarstin extracted from the antarctic lichen Stereocaulon alpinum. Molecules 2018; 23: 658. doi:10.3390/ molecules23030658

[49] Huang Z. Bcl-2 family proteins as targets for anticancer drug design. Oncogene 2000; 19: 6627-6631. doi:10.1038/sj.onc.1204087

[50] Emsen B, Ozdemir O, Engin T, Togar B, Cavusoglu S, Turkez H. Inhibition of growth of U87MG human glioblastoma cells by Usnea longissima Ach. An Acad Bras Cienc 2019; 91: e20180994. doi:10.1590/00013765201920180994

[51] Wisastra R, Dekker F]. Inflammation, cancer and oxidative lipoxygenase activity are intimately linked. Cancers (Basel) 2014; 6: 1500-1521. doi:10.3390/cancers6031500

[52] Ebrahim HY, Elsayed HE, Mohyeldin MM, Akl MR, Bhattacharjee J, Egbert S, El Sayed KA. Norstictic acid inhibits breast cancer cell proliferation, migration, invasion, and in vivo invasive growth through targeting c-Met. Phytother Res 2016; 30: 557-566. doi:10.1002/ptr.5551

[53] Zhang Y, Xia M, Jin K, Wang S, Wei H, Fan C, Wu Y, Li X, Li X, Li G, Zeng Z, Xiong $W$. Function of the c-Met receptor tyrosine kinase in carcinogenesis and associated therapeutic opportunities. Mol Cancer 2018; 17: 45. doi:10.1186/s12943-018-0796-y

[54] Alam MK, Alhhazmi A, DeCoteau JF, Luo Y, Geyer CR. RecA inhibitors potentiate antibiotic activity and block evolution of antibiotic resistance. Cell Chem Biol 2016; 23: 381-391. doi:10.1016/j.chembiol.2016. 02.010

[55] McGillick BE, Kumaran D, Vieni C, Swaminathan S. $\beta$-Hydroxyacyl-acyl carrier protein dehydratase (FabZ) from Francisella tularensis and Yersinia pestis: structure determination, enzymatic characterization, and crossinhibition studies. Biochemistry 2016; 55: 1091-1099. doi:10.1021/ acs.biochem.5b00832 
[56] Feibelman KM, Fuller BP, Li L, LaBarbera DV, Geiss B]. Identification of small molecule inhibitors of the Chikungunya virus nsP1 RNA capping enzyme. Antiviral Res 2018; 154: 124-131. doi:10.1016/j.antiviral.2018. 03.013

[57] Panzhinskiy E, Ren J, Nair S. Pharmacological inhibition of protein tyrosine phosphatase $1 \mathrm{~B}$ : a promising strategy for the treatment of obesity and type 2 diabetes mellitus. Curr Med Chem 2013; 20: 2609-2625. doi:10.2174/0929867311320210001

[58] Klaman LD, Boss O, Peroni OD, Kim JK, Martino JL, Zabolotny JM, Moghal N, Lubkin M, Kim YB, Sharpe AH, Stricker-Krongrad A, Shulman GI, Neel BG, Kahn BB. Increased energy expenditure, decreased adiposity, and tissue-specific insulin sensitivity in protein-tyrosine phosphatase 1B-deficient mice. Mol Cell Biol 2000; 20: 5479-5489. doi:10.1128/ mcb.20.15.5479-5489.2000

[59] Carpentier C, Barbeau X, Azelmat J, Vaillancourt K, Grenier D, Lagüe P, Voyer N. Lobaric acid and pseudodepsidones inhibit NF-KB signaling pathway by activation of PPAR-y. Bioorg Med Chem 2018; 26: 58455851. doi:10.1016/j.bmc.2018.10.035

[60] Lee HW, Kim J, Yim JH, Lee HK, Pyo S. Anti-inflammatory activity of lobaric acid via suppressing NF-KB/MAPK pathways or NLRP3 inflammasome activation. Planta Med 2019; 85: 302-311. doi:10.1055/a-07772420

[61] Millot M, Tomasi S, Articus K, Rouaud I, Bernard A, Boustie J. Metabolites from the lichen Ochrolechia parella growing under two different heliotropic conditions. J Nat Prod 2007; 70: 316-318. doi:10.1021/ np060561p

[62] Bellio P, Segatore B, Mancini A, Di Pietro L, Bottoni C, Sabatini A, Brisdelli F, Piovano M, Nicoletti M, Amicosante G, Perilli M, Celenza G. Interaction between lichen secondary metabolites and antibiotics against clinical isolates methicillin-resistant Staphylococcus aureus strains. Phytomedicine 2015; 22: 223-230. doi:10.1016/j.phymed.2014.12.005

[63] Bellio P, Di Pietro L, Mancini A, Piovano M, Nicoletti M, Brisdelli F, Tondi D, Cendron L, Franceschini N, Amicosante G, Perilli M, Celenza G. SOS response in bacteria: Inhibitory activity of lichen secondary metabolites against Escherichia coli RecA protein. Phytomedicine 2017; 29: 11-18. doi:10.1016/j.phymed.2017.04.001

[64] Yilmaz M, Türk AO, Tay T, Kivanç M. The antimicrobial activity of extracts of the lichen Cladonia foliacea and its (-)-usnic acid, atranorin, and fumarprotocetraric acid constituents. Z Naturforsch CJ Biosci 2004; 59 : 249-254. doi:10.1515/znc-2004-3-423

[65] Ranković B, Misić M, Sukdolak S. Antimicrobial activity of extracts of the lichens Cladonia furcata, Parmelia caperata, Parmelia pertusa, Hypogymnia physodes and Umbilicaria polyphylla. Br J Biomed Sci 2007; 64: 143-148. doi:10.1080/09674845.2007.11732776

[66] Pompilio A, Pomponio S, Di Vincenzo V, Crocetta V, Nicoletti M, Piovano M, Garbarino JA, Di Bonaventura G. Antimicrobial and antibiofilm activity of secondary metabolites of lichens against methicillin-resistant Staphylococcus aureus strains from cystic fibrosis patients. Future Microbiol 2013; 8: 281-292. doi:10.2217/fmb.12.142

[67] Igoli JO, Gray Al, Clements C], Kantheti P, Singla RH. Antitrypanosomal activity \& docking studies of isolated constituents from the lichen Cetraria islandica: possibly multifunctional scaffolds. Curr Top Med Chem 2014; 14: 1014-1021. doi:10.2174/1568026614666140324122323

[68] Fernández-Moriano C, Divakar PK, Crespo A, Gómez-Serranillos MP. In vitro neuroprotective potential of lichen metabolite fumarprotocetraric acid via intracellular redox modulation. Toxicol Appl Pharmacol 2017; 316: 83-94. doi:10.1016/j.taap.2016.12.020

[69] de Barros Alves GM, de Sousa Maia MB, de Souza Franco E, Galvão AM, da Silva TG, Gomes RM, Martins MB, da Silva Falcão EP, de Castro CM, da Silva NH. Expectorant and antioxidant activities of purified fumarprotocetraric acid from Cladonia verticillaris lichen in mice. Pulm Pharmacol Ther 2014; 27: 139-143. doi:10.1016/j.pupt.2013.07.002
[70] Lohézic-Le Dévéhat F, Legouin B, Couteau C, Boustie J, Coiffard L. Lichenic extracts and metabolites as UV filters. J Photochem Photobiol B 2013; 120: 17-28. doi:10.1016/j.jphotobiol.2013.01.009

[71] Pavlovic V, Stojanovic I, Jadranin M, Vajs V, Djordjević I, Smelcerovic A, Stojanovic G. Effect of four lichen acids isolated from Hypogymnia physodes on viability of rat thymocytes. Food Chem Toxicol 2013; 51: 160-164. doi:10.1016/j.fct.2012.04.043

[72] Cetin H, Tufan-Cetin O, Turk AO, Tay T, Candan M, Yanikoglu A, Sumbul H. Larvicidal activity of some secondary lichen metabolites against the mosquito Culiseta longiareolata Macquart (Diptera: Culicidae). Nat Prod Res 2012; 26: 350-355. doi:10.1080/14786411003774296

[73] Yilmaz M, Tay T, Kivanç M, Türk H, Türk AO. The antimicrobial activity of extracts of the lichen Hypogymnia tubulosa and its 3-hydroxyphysodic acid constituent. Z Naturforsch C J Biosci 2005; 60: 35-38. doi:10.1515/znc-2005-1-207

[74] Ogmundsdóttir HM, Zoëga GM, Gissurarson SR, Ingólfsdóttir K. Antiproliferative effects of lichen-derived inhibitors of 5-lipoxygenase on malignant cell-lines and mitogen-stimulated lymphocytes. J Pharm Pharmacol 1998; 50: 107-115. doi:10.1111/j.2042-7158.1998.tb03312.x

[75] Bucar F, Schneider I, Ogmundsdóttir H, Ingólfsdóttir K. Anti-proliferative lichen compounds with inhibitory activity on 12(S)-HETE production in human platelets. Phytomedicine 2004; 11: 602-606. doi:10.1016/j. phymed.2004.03.004

[76] Brisdelli F, Perilli M, Sellitri D, Piovano M, Garbarino JA, Nicoletti M, Bozzi A, Amicosante G, Celenza G. Cytotoxic activity and antioxidant capacity of purified lichen metabolites: an in vitro study. Phytother Res 2013; 27: 431-437. doi:10.1002/ptr.4739

[77] Haraldsdóttir S, Guolaugsdóttir E, Ingólfsdóttir K, Ogmundsdóttir HM. Anti-proliferative effects of lichen-derived lipoxygenase inhibitors on twelve human cancer cell lines of different tissue origin in vitro. Planta Med 2004; 70: 1098-1100. doi:10.1055/s-2004-832657

[78] Morita H, Tsuchiya T, Kishibe K, Noya S, Shiro M, Hirasawaa Y. Antimitotic activity of lobaric acid and a new benzofuran, sakisacaulon A from Stereocaulon sasakii. Bioorg Med Chem Lett 2009; 19: 3679-3681. doi:10.1016/j.bmcl.2009.03.170

[79] Ozgencli I, Budak H, Ciftci M, Anar M. Lichen acids may be used as a potential drug for cancer therapy; by inhibiting mitochondrial thioredoxin reductase purified from rat lung. Anticancer Agents Med Chem 2018; 18: 1599-1605. doi:10.2174/1871520618666180525095520

[80] Seo C, Sohn JH, Ahn JS, Yim JH, Lee HK, Oh H. Protein tyrosine phosphatase $1 \mathrm{~B}$ inhibitory effects of depsidone and pseudodepsidone metabolites from the antarctic lichen Stereocaulon alpinum. Bioorg Med Chem Lett 2009; 19: 2801-2803. doi:10.1016/j.bmcl.2009.03.108

[81] Kim TK, Kim JE, Youn U], Han SJ, Kim IC, Cho CG, Yim JH. Total syntheses of lobaric acid and its derivatives from the antarctic lichen Stereocaulon alpinum. J Nat Prod 2018; 81: 1460-1467. doi:10.1021/acs.jnatprod. $8 \mathrm{~b} 00227$

[82] Joo YA, Chung H, Yoon S, Park Jl, Lee JE, Myung CH, Hwang JS. Skin barrier recovery by Protease-Activated Receptor-2 antagonist lobaric acid. Biomol Ther (Seoul) 2016; 24: 529-535. doi:10.4062/biomolther. 2016.011

[83] Kwon IS, Yim JH, Lee HK, Pyo S. Lobaric acid inhibits VCAM-1 expression in TNF- $\alpha$-stimulated vascular smooth muscle cells via modulation of NFKB and MAPK signaling pathways. Biomol Ther (Seoul) 2016; 24: 25-32. doi:10.4062/biomolther.2015.084

[84] Ingolfsdottir K, Gissurarson SR, Müller-Jakic B, Breu W, Wagner H. Inhibitory effects of the lichen metabolite lobaric acid on arachidonate metabolism in vitro. Phytomedicine 1996; 2: 243-246. doi:10.1016/ S0944-7113(96)80049-3

[85] Ingólfsdóttir K, Chung GA, Skúlason VG, Gissurarson SR, Vilhelmsdóttir $M$. Antimycobacterial activity of lichen metabolites in vitro. Eur J Pharm Sci 1998; 6: 141-144. doi:10.1016/s0928-0987(97)00078-x 
[86] Vankadari N, Jeyasankar NN, Lopes WJ. Structure of the SARS-CoV-2 Nsp1/5'-untranslated region complex and implications for potential therapeutic targets, a vaccine, and virulence. J Phys Chem Lett 2020; 11: 9659-9668. doi:10.1021/acs.jpclett.0c02818

[87] Thadhani VM, Choudhary MI, Ali S, Omar I, Siddique H, Karunaratne V. Antioxidant activity of some lichen metabolites. Nat Prod Res 2011; 25: 1827-1837. doi:10.1080/14786419.2010.529546

[88] Gissurarson SR, Sigurdsson SB, Wagner H, Ingolfsdottir K. Effect of lobaric acid on cysteinyl-leukotriene formation and contractile activity of guinea pig taenia coli. J Pharmacol Exp Ther 1997; 280: 770-773

[89] Brandão LF, Alcantara GB, Matos Mde F, Bogo D, Freitas Ddos S, Oyama NM, Honda NK. Cytotoxic evaluation of phenolic compounds from lichens against melanoma cells. Chem Pharm Bull (Tokyo) 2013; 61: 176-183. doi:10.1248/cpb.c12-00739

[90] Ranković B, Kosanić M, Stanojković T, Vasiljević P, Manojlović N. Biological activities of Toninia candida and Usnea barbata together with their norstictic acid and usnic acid constituents. Int J Mol Sci 2012; 13 : 14707-14722. doi:10.3390/ijms131114707

[91] Ismed F, Dévéhat FL, Rouaud I, Ferron S, Bakhtiar A, Boustie J. NMR reassignment of stictic acid isolated from a Sumatran lichen Stereocaulon montagneanum (Stereocaulaceae) with superoxide anion scavenging activities. Z Naturforsch C J Biosci 2017; 72: 55-62. doi:10.1515/znc2016-0148

[92] Tay T, Türk AO, Yilmaz M, Türk H, Kivanç M. Evaluation of the antimicrobial activity of the acetone extract of the lichen Ramalina farinacea and its (+)-usnic acid, norstictic acid, and protocetraric acid constituents. Z Naturforsch C J Biosci 2004; 59: 384-388. doi:10.1515/ znc-2004-5-617

[93] Honda NK, Pavan FR, Coelho RG, de Andrade Leite SR, Micheletti AC, Lopes TI, Misutsu MY, Beatriz A, Brum RL, Leite CQ. Antimycobacterial activity of lichen substances. Phytomedicine 2010; 17: 328-332. doi:10.1016/j.phymed.2009.07.018

[94] Russo A, Piovano M, Lombardo L, Vanella L, Cardile V, Garbarino J. Pannarin inhibits cell growth and induces cell death in human prostate carcinoma DU-145 cells. Anticancer Drugs 2006; 17: 1163-1169. doi:10.1097/01.cad.0000236310.66080.ed

[95] Russo A, Piovano M, Lombardo L, Garbarino J, Cardile V. Lichen metabolites prevent UV light and nitric oxide-mediated plasmid DNA damage and induce apoptosis in human melanoma cells. Life Sci 2008; 83 : 468-474. doi:10.1016/j.Ifs.2008.07.012

[96] Hidalgo ME, Fernández E, Quilhot W, Lissi EA. Photohemolytic activity of lichen metabolites. J Photochem Photobiol B 1993; 21: 37-40. doi:10.1016/1011-1344(93)80161-2

[97] Celenza G, Segatore B, Setacci D, Bellio P, Brisdelli F, Piovano M, Garbarino JA, Nicoletti M, Perilli M, Amicosante G. In vitro antimicrobial activity of pannarin alone and in combination with antibiotics against methicillin-resistant Staphylococcus aureus clinical isolates. Phytomedicine 2012; 19: 596-602. doi:10.1016/j.phymed.2012.02.010

[98] Fournet A, Ferreira ME, Rojas de Arias A, Torres de Ortiz S, Inchausti A, Yaluff G, Quilhot W, Fernandez E, Hidalgo ME. Activity of compounds isolated from Chilean lichens against experimental cutaneous leishmaniasis. Comp Biochem Physiol C Pharmacol Toxicol Endocrinol 1997; 116: 51-54. doi:10.1016/s0742-8413(96)00127-2

[99] Fernández E, Reyes A, Hidalgo ME, Quilhot W. Photoprotector capacity of lichen metabolites assessed through the inhibition of the 8-methoxypsoralen photobinding to protein. J Photochem Photobiol B 1998; 42: 195-201. doi:10.1016/s1011-1344(98)00070-0

[100] Cardile V, Graziano ACE, Avola R, Piovano M, Russo A. Potential anticancer activity of lichen secondary metabolite physodic acid. Chem Biol Interact 2017; 263: 36-45. doi:10.1016/j.cbi.2016.12.007

[101] Kosanić M, Manojlović N, Janković S, Stanojković T, Ranković B. Evernia prunastri and Pseudoevernia furfuraceae lichens and their major metabolites as antioxidant, antimicrobial and anticancer agents. Food Chem Toxicol 2013; 53: 112-118. doi:10.1016/j.fct.2012.11.034
[102] Studzińska-Sroka E, Piotrowska H, Kucińska M, Murias M, Bylka W. Cytotoxic activity of physodic acid and acetone extract from Hypogymnia physodes against breast cancer cell lines. Pharm Biol 2016; 54 : 2480-2485. doi:10.3109/13880209.2016.1160936

[103] Emsen B, Aslan A, Togar B, Turkez H. In vitro antitumor activities of the lichen compounds olivetoric, physodic and psoromic acid in rat neuron and glioblastoma cells. Pharm Biol 2016; 54: 1748-1762. doi:10.3109/ 13880209.2015.1126620

[104] Stojanović IZ, Stanković M, Jovanović O, Petrović G, Smelcerović A, Stojanović GS. Effect of Hypogymnia physodes extracts and their depsidones on micronucleus distribution in human lymphocytes. Nat Prod Commun 2013; 8: 109-112

[105] Stojanović IZ, Najman S, Jovanović O, Petrović G, Najdanović J, Vasiljević P, Smelcerović A. Effects of depsidones from Hypogymnia physodes on HeLa cell viability and growth. Folia Biol (Praha) 2014; 60: 89-94

[106] Talapatra SK, Rath O, Clayton E, Tomasi S, Kozielski F. Depsidones from lichens as natural product inhibitors of M-Phase Phosphoprotein 1, a human kinesin required for cytokinesis. J Nat Prod 2016; 79: 15761585. doi:10.1021/acs.jnatprod.5b00962

[107] Bauer J, Waltenberger B, Noha SM, Schuster D, Rollinger JM, Boustie J, Chollet M, Stuppner H, Werz O. Discovery of depsides and depsidones from lichen as potent inhibitors of microsomal prostaglandin E2 synthase-1 using pharmacophore models. ChemMedChem 2012; 7: 2077-2081. doi:10.1002/cmdc.201200345

[108] Emsen B, Turkez H, Togar B, Aslan A. Evaluation of antioxidant and cytotoxic effects of olivetoric and physodic acid in cultured human amnion fibroblasts. Hum Exp Toxicol 2017; 36: 376-385. doi:10.1177/0960327116650012

[109] Emsen B, Togar B, Turkez H, Aslan A. Effects of two lichen acids isolated from Pseudevernia furfuracea (L.) Zopf in cultured human lymphocytes. Z Naturforsch C J Biosci 2018; 73: 303-312. doi:10.1515/znc2017-0209

[110] Reddy RG, Veeraval L, Maitra S, Chollet-Krugler M, Tomasi S, Dévéhat FL, Boustie J, Chakravarty S. Lichen-derived compounds show potential for central nervous system therapeutics. Phytomedicine 2016; 23 : 1527-1534. doi:10.1016/j.phymed.2016.08.010.

[111] Osawa T, Kumon H, Reece CA, Shibamoto T. Inhibitory effect of lichen constituents on mutagenicity induced by heterocyclic amines. Environ Mol Mutagen 1991; 18: 35-40. doi:10.1002/em.2850180107

[112] Nishanth KS, Sreerag RS, Deepa I, Mohandas C, Nambisan B. Protocetraric acid: an excellent broad spectrum compound from the lichen Usnea albopunctata against medically important microbes. Nat Prod Res 2015; 29: 574-577. doi:10.1080/14786419.2014.953500

[113] Dieu A, Mambu L, Champavier Y, Chaleix V, Sol V, Gloaguen V, Millot M. Antibacterial activity of the lichens Usnea Florida and Flavoparmelia caperata (Parmeliaceae). Nat Prod Res 2020; 34: 3358-3362. doi:10.1080/14786419.2018.1561678

[114] Deraeve C, Guo Z, Bon RS, Blankenfeldt W, DiLucrezia R, Wolf A Menninger S, Stigter EA, Wetzel S, Choidas A, Alexandrov K, Waldmann H, Goody RS, Wu YW. Psoromic acid is a selective and covalent Rab-prenylation inhibitor targeting autoinhibited RabGGTase. J Am Chem Soc 2012; 134: 7384-7391. doi:10.1021/ja211305j

[115] Samatov TR, Wolf A, Odenwälder P, Bessonov S, Deraeve C, Bon RS, Waldmann H, Lührmann R. Psoromic acid derivatives: a new family of small-molecule pre-mRNA splicing inhibitors discovered by a stagespecific high-throughput in vitro splicing assay. Chembiochem 2012 ; 13: 640-644. doi:10.1002/cbic.201100790

[116] Hassan STS, Šudomová M, Berchová-Bímová K, Šmejkal K, Echeverría J. Psoromic acid, a lichen-derived molecule, inhibits the replication of HSV-1 and HSV-2, and inactivates HSV-1 DNA polymerase: shedding light on antiherpetic properties. Molecules 2019; 24: 2912. doi:10.3390/molecules24162912 
[117] Sweidan A, Chollet-Krugler M, Sauvager A, van de Weghe P, Chokr A, Bonnaure-Mallet M, Tomasi S, Bousarghin L. Antibacterial activities of natural lichen compounds against Streptococcus gordonii and Porphyromonas gingivalis. Fitoterapia 2017; 121: 164-169. doi:10.1016/j.fitote. 2017.07.011

[118] Hassan STS, Šudomová M, Berchová-Bímová K, Gowrishankar S, Rengasamy KRR. Antimycobacterial, enzyme inhibition, and molecular interaction studies of psoromic acid in Mycobacterium tuberculosis: efficacy and safety investigations. J Clin Med 2018; 7: 226. doi: $10.3390 / j \mathrm{~cm} 7080226$

[119] Lauinger IL, Vivas L, Perozzo R, Stairiker C, Tarun A, Zloh M, Zhang X, Xu H, Tonge PJ, Franzblau SG, Pham DH, Esguerra CV, Crawford AD, Maes L, Tasdemir D. Potential of lichen secondary metabolites against Plasmodium liver stage parasites with FAS-II as the potential target. J Nat Prod 2013; 76: 1064-1070. doi:10.1021/np400083k

[120] Behera BC, Mahadik N, Morey M. Antioxidative and cardiovascular-protective activities of metabolite usnic acid and psoromic acid produced by lichen species Usnea complanata under submerged fermentation. Pharm Biol 2012; 50: 968-979. doi:10.3109/13880209.2012.654396

[121] Candan M, Yilmaz M, Tay T, Erdem M, Türk AO. Antimicrobial activity of extracts of the lichen Parmelia sulcata and its salazinic acid constituent. Z Naturforsch C J Biosci 2007; 62: 619-621. doi:10.1515/znc2007-7-827

[122] Goel M, Dureja P, Rani A, Uniyal PL, Laatsch H. Isolation, characterization and antifungal activity of major constituents of the Himalayan lichen Parmelia reticulata Tayl. J Agric Food Chem 2011; 59: 22992307. doi:10.1021/jf1049613

[123] Gaikwad S, Verma N, Sharma BO, Behera BC. Growth promoting effects of some lichen metabolites on probiotic bacteria. J Food Sci Technol 2014; 51: 2624-2631. doi:10.1007/s13197-012-0785-x

[124] de Paz GA, Raggio J, Gómez-Serranillos MP, Palomino OM, GonzálezBurgos E, Carretero ME, Crespo A. HPLC isolation of antioxidant constituents from Xanthoparmelia spp. J Pharm Biomed Anal 2010; 53: 165-171. doi:10.1016/j.jpba.2010.04.013
[125] Burlando B, Ranzato E, Volante A, Appendino G, Pollastro F, Verotta L. Antiproliferative effects on tumor cells and promotion of keratinocyte wound healing by different lichen compounds. Planta Med 2009; 75: 607-613. doi:10.1055/s-0029-1185329

[126] Papadopoulou P, Tzakou O, Vagias C, Kefalas P, Roussis V. Beta-orcinol metabolites from the lichen Hypotrachyna revoluta. Molecules 2007; 12: 997-1005. doi:10.3390/12050997

[127] Wassman CD, Baronio R, Demir Ö, Wallentine BD, Chen CK, Hall LV, Salehi F, Lin DW, Chung BP, Hatfield GW, Richard Chamberlin A, Luecke $\mathrm{H}$, Lathrop RH, Kaiser P, Amaro RE. Computational identification of a transiently open L1/S3 pocket for reactivation of mutant p53. Nat Commun 2013; 4: 1407. doi:10.1038/ncomms2361

[128] Omar SI, Tuszynski J. Ranking the binding energies of p53 mutant activators and their ADMET properties. Chem Biol Drug Des 2015; 86: 163-172. doi:10.1111/cbdd. 12480

[129] Russo A, Caggia S, Piovano M, Garbarino ], Cardile V. Effect of vicanicin and protolichesterinic acid on human prostate cancer cells: role of Hsp70 protein. Chem Biol Interact 2012; 195: 1-10. doi:10.1016/j. cbi.2011.10.005

[130] Sanjaya A, Avidlyandi A, Adfa M, Ninomiya M, Koketsu M. A new depsidone from Teloschistes flavicans and the antileukemic activity. J Oleo Sci 2020; 69: 1591-1595. doi:10.5650/jos.ess20209

[131] Bay MV, Nam PC, Quang DT, Mechler A, Hien NK, Hoa NT, Vo QV. Theoretical study on the antioxidant activity of natural depsidones. ACS Omega 2020; 5: 7895-7902. doi:10.1021/acsomega.9b04179

[132] Leal A, Rojas JL, Valencia-Islas NA, Castellanos L. New $\beta$-orcinol depsides from Hypotrachyna caraccensis, a lichen from the páramo ecosystem and their free radical scavenging activity. Nat Prod Res 2018; 32: 1375-1382. doi:10.1080/14786419.2017.1346639

[133] Bui VM, Duong TH, Chavasiri W, Nguyen KP, Huynh BL. A new depsidone from the lichen Usnea ceratina. Nat Prod Res 2020. doi:10.1080/ 14786419.2020.1828405 